\title{
A Study and Factor Identification of Municipal Solid Waste Management in Mexico City
}

\author{
Francisco Gutiérrez Galicia $1, * \mathbb{C}$, Ana Lilia Coria Páez ${ }^{2}$ and Ricardo Tejeida Padilla ${ }^{3}$ (i) \\ 1 Instituto Politécnico Nacional, UPIIH, Pachuca CP 41162, Mexico \\ 2 Instituto Politécnico Nacional, ESCA Tepepan, Mexico City CP 16020, Mexico; acoria@ipn.mx \\ 3 Instituto Politécnico Nacional, EST, Mexico City CP 07630, Mexico; rtejeidap@ipn.mx \\ * Correspondence: fgutierrezga@ipn.mx; Tel.: +52-55-57296000 (ext. 83909)
}

Received: 12 September 2019; Accepted: 4 November 2019; Published: 9 November 2019

\begin{abstract}
Mexico City generates 12 thousand tons of Municipal Solid Waste (MSW) per day, which places it as one of the cities that produces the most MSW in the world. However, the treatments used in the city are not enough for recycling materials and organics valorization of at least $45 \%$ of the MSW, which is the minimum for a medium-high-income city. To put in a global context the deficiency in Municipal Solid Waste Management (MSWM) in Mexico City and evaluate the policies that have been implemented thus far, Wasteaware benchmark Indicators for Integrated Sustainable Waste Management (ISWM) were used to obtain a desired profile for the comprehensive MSWM in Mexico City. The Wasteaware Benchmark Indicators have been tested in more than 50 cities around the world. The results showed that in Mexico City, certain aspects of governance present the most considerable delay and, at the same time, that there are certain areas of opportunity to improve the efficiency of MSWM in its physical aspects, such as collection systems or treatment services.
\end{abstract}

Keywords: solid waste management; indicators; Mexico City

\section{Introduction}

\subsection{Waste Management of Megacities}

Municipal solid waste management (MSWM) is a major issue in countries worldwide. The world generates 2.01 billion tons of Municipal Solid Waste (MSW) annually, with at least 33 percent of that not managed in an environmentally safe manner. Worldwide, waste generated per person per day averages $0.74 \mathrm{~kg}$ but ranges widely, from 0.11 to $4.54 \mathrm{~kg}$ [1]. This problem is more sensitive in developing countries because the total amount of MSW has dramatically increased due to rapid urbanization and industrialization in the cities of these countries [2].

Economic power and global production are shifting from the traditionally industrialized countries to new global hubs in developing and transition countries. In 2050, it is expected that the global population will have grown more than $50 \%$ compared to 2007 and that two-thirds of the world's population will live in urban areas [3]. As countries develop from low-income to middle- and high-income levels, their waste management situations will also evolve. Growth in prosperity and movement to urban areas are linked to increases in per capita generation of MSW [1]. Furthermore, rapid urbanization and population growth create larger population centers, making the collection of all waste and the procuring of land for treatment and disposal more and more difficult, in developing countries, the aim is to increase the coverage of the waste collection service and to minimize uncontrolled or illegal dumping (upgrading to sanitary landfilling) [4].

Megacities (cities with a total population over a 10 million people) are a product of this urbanization process. A megacity can be a single city or metropolitan area or two or more metropolitan areas that 
converge [5]. The number of megacities is increasing, and by 2015, there will be 33 megacities, 27 of them in the developing world [3]. In megacities, the role of waste management is becoming crucial both for daily life and for sustainability [6]. Waste management systems in a megacity, is a great challenge, because of the complexity of the system. There is no 'one size fits all' solution that can be implemented globally, and every solution implemented has to address the physical elements and the governance issues of the waste management system. The International Solid Waste Association established in 2014, eight main challenges for the effective MSWM in megacities, four related to physical aspects, and four for governance issues [3].

Regarding physical aspects, the first challenge in a megacity is the large amount of MSW generated; it is necessary to focus on waste prevention and recycling programs to develop decentralized recycling initiatives, including the organic fraction [7]. The second issue to consider is health and environmental risks from inadequate waste management, increasing collection coverage, particularly to areas of the city that are most vulnerable, and the phasing out of uncontrolled disposal $[4,8]$. Another problem is the lack of infrastructure that is generally not built on time, due to lack of economic resources [9]. An alternative is the construction of decentralized facilities at a smaller scale and cost using the experience of local contractors and involving the informal sector whenever possible while waiting for the implementation of a more expensive centralized infrastructure [10]. Finally, the city government must define land uses as soon as possible and ensure the availability of land for the construction of waste management infrastructure as soon as possible [7], to face whit the lack of space due to rapid urbanization [5].

Regarding governance issues, due to its extension, megacities have a plethora of institutions involved. It is necessary to create metropolitan authorities to coordinate activities and try to keep legal responsibilities as clear as possible, without overlaps, as representative waste management platforms to share the responsibilities with all the stakeholders involved [11]. The second issue in megacities in developing countries is the informal sector, one of the most important interest groups that have a primary role in the recycling of MSW $[8,12,13]$. Necessary analyze local market dynamics and learn from on-going activities when planning and implementing new waste management initiatives, its recommend search for low-cost solutions that might be generalized for the formal and informal sector [9]. Another problem is the inhabitants, who in the megacities are mosaics of communities, so the solution for waste management must also be a mosaic. It is necessary to develop a variety of solutions that adapt to different parts of the city, but with specific limitations that protect human health and the environment [7]. Finally, a lack of data to plan and implement is common in megacities; both wastes generated and waste composition needs to be routinely measured, and flow diagrams should be drawn to document the material flows through a city's waste management and recycling system $[4,11]$. It is recommended that the city government develop and implement strategic waste management plans instead of detailed master plans and establish entities with responsible officers with the authority and capacity to propose, implement, and operate suitable waste management solutions [9]. Big data systems will be a crucial tool whenever and wherever they are established [10].

\subsubsection{Background Information on Mexico City}

The United Nations (UN) ranks the metropolitan area of Mexico City, Mexico, with 19 million inhabitants in 2007, as among the five most populous urban areas in the world. Mexico City concentrates $30 \%$ of the national urban population and is the third most populated agglomeration in the world [14], as well as the main political, economic, scientific, and cultural center of the country; this, combined with the large number of activities, places of interest, and work centers, gives the city an accelerated pace of life that is reflected directly in the consumption and use of natural resources, with a direct impact on the generation of MSW (according to the national regulations these are those that generated in homes and public spaces) typical of a megacity.

Among global megacities, Mexico City generates the most waste after the New York region: 12 thousand tons of MSW per day [15]. The management of this MSW is a challenge for City government, 
in terms of both the amount generated and the density of traffic and the lack of adequate areas to carry out its treatment and final disposal according to existing environmental regulations. The MSWM in the city of Mexico is carried out by three different groups: the public cleaning service that performs the collection and final disposal, the informal workers who perform the separation of MSW for recycling, and private companies that provide collection and final disposal services for businesses and industries. Privately hired street sweepers and municipal employees also negotiate and coordinate their actions so that their work does not overlap, and rather complements each other. Nevertheless, this de facto collaboration is not recognized institutionally: official reports and urban waste strategies only address the public provision of waste collection and management services [12].

\subsubsection{Policies and Current Practices of the MSWM in Mexico City}

The National Policy on Solid Waste in Mexico focused on the construction of sanitary landfills [14]. In contrast to the National Policy, Mexico City considers, as an ideal alternative to the problem of MSW, prevention and minimization actions so that the majority of the MSW does not end up in a final disposal site; there are alternatives that allow users to recycle or reuse the MSW that they generate, and the aim is increasing to reduce cleaning services such as collection, transfer, final disposal, and treatment $[14,16,17]$.

In 2004, Mexico City published its waste law, which was the first in the country to establish waste separation, and in 2008, the regulations of the Waste Law were published, establishing penalties for those who do not comply with the separation of the MSW [18,19].

\subsection{Uncertainties in MSWM of Mexico City}

In recent research conducted in Mexico City about MSWM, four main problems have detected that are: weak institution, compliance with regulations, lack of new infrastructure, and lack of income for MSW services, as described below.

Waste is a sector in which the Mexico City government has relatively little control. The City government is in charge of public services and complemented by two alternative systems [20]: private services and informal. Nevertheless, the City government does not have records of the number of informal workers, their organization, and the amount of MSW they recover, while the private companies do not have records of the MSW they collect, and what their destinations are. These three groups work in coordination. However, in the current situation, the City government cannot have the capacity to direct or to otherwise management these three groups to increase the amount of MSW recycled or to diminish the effects on the environment. The regulations of the law on waste for those who do not perform proper separation of MSW are not applied, leading to the low participation of users and service providers in the separation of MSW for its valorization. Thus, more than $60 \%$ of the MSW is sent to landfills in the entities neighboring Mexico City [21].

In Mexico City, since the middle of the last century, the destination of the MSW was the Bordo Pontine Landfill, except those recycled by the informal sector. In 2011, large-scale organic waste began to be treated at the compost plant where the Bordo Poniente landfill was previously located [22]. Currently, Mexico City needs to increase the MSW recycling rate, since most of its MSWs are send to private landfills in neighboring states [21]. For treatments with better efficiency than separation and compost plants, such as heat treatment, Tsydenova et al. indicated the importance of introducing waste incineration is sustainable from the environmental, economic, and social aspects of waste that cannot be sent to organic treatments and/or recycled [23].

However, this project could not complete due to the position of the population and environmental groups to its proximity to urban areas. As the lack of space and "Not In My Backyard" NIMBY reaction to proposals for any new waste management facility, no matter how clean or sustainable that may be [9], has had the result that the infrastructure for the MSWM has not grown or diversified. Because Mexico City does not have the resources (for the lack of payment) for users to include other types of management options, most of it goes to the collection, transport, and final disposal, and the informal 
workers make the recovery of MSW with their scarce resources. For a country with a high average income level like Mexico, it would be expected to have not only sanitary landfills and compost plants, but also anaerobic treatment and incineration with energy recovery [4].

The limited budget and the need to increase the capacity of the cleaning services have caused, instead of creating new jobs, volunteers to be accepted in the collection and sweep services to cover these deficiencies [12]. In public collection service, municipal employees (truck drivers) and volunteers cover the routes and removing recycled waste asking for tips [24], higher tips, and more valuable salvaged materials get better service [25]. The authorities tolerate the requirement of tips because part of them is saved to give maintenance to garbage trucks [12].

As a consequence of the above, the inhabitant of Mexico City must make a payment, at least for the collection services. It is contradictory that the inhabitants need to make an expense so that the collection vehicles remain in operation, and the government does not administer economic resources without the possibility of taking advantage of the economy of scale.

To improve waste management systems, strategic planning needs to be done to document, understand, and build on existing systems that include the informal sector. All the experiences demonstrate that it will be more expensive and less useful to construct a new formal system ignoring the already established one [26-28]. The starting point for improvement is to analyze the current successes and failures of the existing system, and its strong and weak points [10]. New tools, techniques, and policies are required to measure the baseline and to monitor growth and change across the megacity [29].

\subsection{Aim of Research}

Several tools have proposed to improve and promote the progress of MSWM, some of them based on the use of indicators [30]. Indicators are commonly used to evaluate the environmental performance of MSWM systems and to provide valuable information for waste managers and policymakers and, they can help in evaluating internal programmatic performance and progress [31]. Turcott Cervantes et al. analyzed the main characteristics, strengths, and weaknesses of 40 sets of waste indicators. They concluded that The Zero Waste Index [32] and "Wasteaware" benchmark indicators for Integrated Sustainable Waste Management (ISWM) in cities [33] are the most complete and adaptable set of indicators to any income city.

The aim of this research evaluated the efficiency of the policies and programs implemented in Mexico City in the last decade. Wasteaware indicators selected for the evaluation of the MSWM in Mexico City, because are the most accepted and recognized by government authorities [30] and have applied in megacities with an medium-income level [34-36], whereby the current performance of the city's current performance can put into a global context.

This research evaluated the efficient waste management in Mexico City during the period 2011-2017, using the Wasteaware benchmark indicators, this period selected because in 2011 the final disposal site at Bordo Poniente was closed (which represented the most significant change in the MSWM in the city) [25]. Wasteaware benchmark indicators found appropriate for this research because they are designed to be applied in any city, independently of its level of development. Wasteaware benchmark indicators approach covers all aspects of Integrated Sustainable Waste Management (ISWM), in terms of both physical components and governance [33]. This research provides a full dataset related to waste collection, recycling, disposal, inclusivity, financial sustainability, sound institutions, and proactive policies. As a result, an exhaustive of the available statistical information and data in MWS inventory performed. Wasteawae benchmark indicators could be usefully for decision making related to new policies or enhancement of waste management of the city to improve, especially in aspects related to governance.

\section{Materials and Methods}

The analysis framework built around the concept of Integrated Sustainable Waste Management' (ISWM) is a systematic way of thinking about waste management. This approach provides insights 
into certain aspects, such as environmental, social, and legal aspects; the stakeholders, namely waste pickers, small-scale enterprises, and female heads of household; and practical or technical elements of the waste management system, including prevention, reuse, and recycling [37].

ISWM has three major dimensions: (1) the stakeholders involved in waste management, (2) the (practical and technical) elements of the waste system, and (3) the aspects of the local context that should be taken into account when assessing and planning a waste management system [37]. The ISWM concept distinguishes six components, through which the existing waste system can be assessed and with which a new or expanded system can plan. The six components of ISWM are technical and performance, environmental, financial-economic, political/legal, institutional, and socio-cultural. The three dimensions and six components of ISWM can summarize in two triangles: the first represents the physical elements of the waste systems, and the second governance, both in the framework of the local context, as shown in Figure 1.

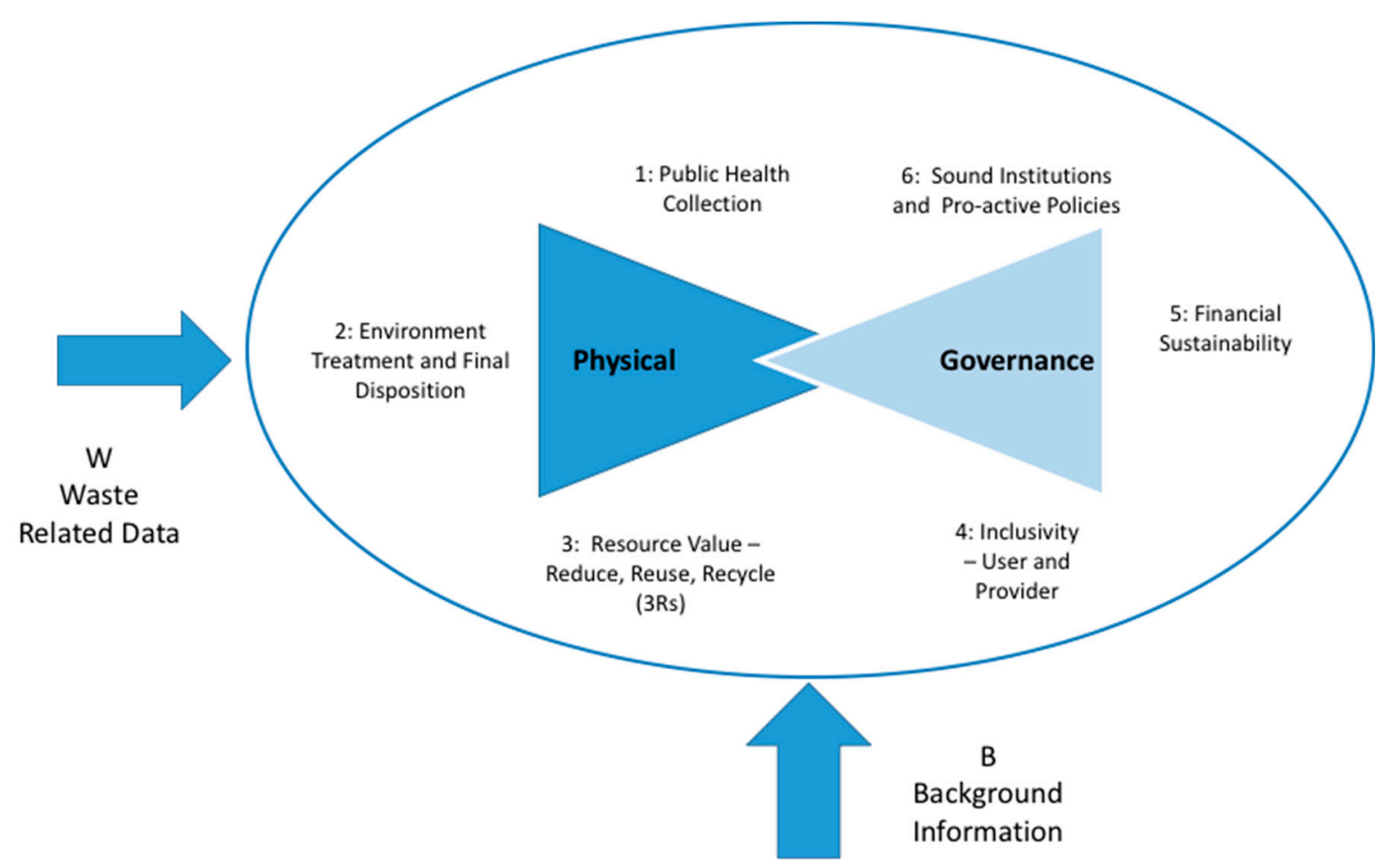

Figure 1. The Integrated Sustainable Waste Management (ISWM) framework used by the Wasteaware indicator set [33,37].

The Wastaeware benchmark indicators were developed in 2012 and 2013 by researchers from multiple institutions, with the support of German Corporation for International Cooperation and the German Federal Ministry for Economic Cooperation and Development. Wasteaware benchmark indicators provide an overview of a city's solid waste management performance, to reveal clearly those aspects which are performing well and not so well, in order to point the way to the next steps on the road to improvement and to allow benchmarking against other cities [33].

The evaluation process of the performance of a city waste management is summarized in Figure 1. Each aspect has its components that are evaluated to determine the degree of compliance to have an integrated system with the information available about solid waste and the context of the city $[37,38]$. There are five levels of compliance, and each of the indicators has a weighting to determine the degree of compliance, identified using a 'traffic light' system, where: low = red (0-49\%); low-medium = red/orange (50-69\%); medium = orange (70-89\%); medium-high = orange/green (90-98\%); and high = green $(99-100 \%)$. The exception is the recycling rate, which has its weighting as indicated in Appendix A [33]. 
Figure 1 shows all the components of the ISWM, each related to its key driver. On the left are the physical components: (1) waste collection driven primarily by public health; (2) waste treatment and disposal, mainly driven by environmental protection; and (3) the 3Rs (reduce, reuse, recycle), driven by the value of waste resources [39]. On the right are the three key components of governance and their drivers, which are: (4) inclusion of stakeholders driven by the inclusion of users and service providers; (5) financial sustainability, which requires the system to be profitable, affordable, and well-funded; and a base of (6) sound institutions and pro-active policies [33,39]. Each component is evaluated with qualitative and or quantitative indicators, as shown in Table 1.

Table 1. Set of indicators [33].

\begin{tabular}{|c|c|c|}
\hline & Components & Indicator \\
\hline \multirow{3}{*}{$\begin{array}{l}\text { Background } \\
\text { information }\end{array}$} & \multirow{3}{*}{ Waste-related data } & B.1 National income \\
\hline & & W.1 Waste per capita \\
\hline & & W.2 Waste composition \\
\hline \multirow{7}{*}{ Physical Aspects } & \multirow{3}{*}{ Public health waste collection } & 1.1 Waste collection coverage \\
\hline & & 1.2 Waste captured by the system \\
\hline & & 1.3 Quality of waste collection service \\
\hline & \multirow{2}{*}{$\begin{array}{c}\text { Environmental control } \\
\text { (waste treatment and disposal) }\end{array}$} & 2 Controlled treatment and disposal \\
\hline & & $\begin{array}{l}\text { 2E Degree of environmental protection in waste } \\
\text { treatment and disposal }\end{array}$ \\
\hline & \multirow{2}{*}{$\begin{array}{l}\text { Resource management } \\
\text { (reduce, reuse and recycle) }\end{array}$} & 3 Recycling rates \\
\hline & & 3R Quality of 3Rs (Reduce, Reuse and Recycle) \\
\hline \multirow{5}{*}{ Governance } & User inclusivity & $4 \mathrm{U}$ User inclusivity \\
\hline & Provider inclusivity & 4P Provider inclusivity \\
\hline & Financial sustainability & 5F Financial sustainability \\
\hline & $\begin{array}{l}\text { Adequacy of national } \\
\text { SWM framework }\end{array}$ & 6N Adequacy of national SWM framework \\
\hline & Local institutional coherence & 6L Local institutional coherence \\
\hline
\end{tabular}

The evaluation by reference indicators uses different scales depending on national income. The scale used for high-income countries, it evaluates with greater rigor the physical aspects because it considered that there is greater accessibility to more advanced technology for the MSWM. For countries with medium and low income, the scale is less strict, since they have greater difficulty in acquiring new technologies, and some of the more rigorous scales cannot adjust to the composition of the MSW of the countries with lower income where the organic fraction predominates [33].

Qualitative indicators in Mexico City were obtained for interviews with key informants and supplemented with official reports (see Appendix B), and quantitative indicators calculated with data from official and scientific articles (see Appendix C). A comparison with other cities in the world was made with three megacities with a similar number of inhabitants ( 9 million inhabitants) with an average income level, Bangkok [36], with a medium-high income, Zhengzhou [34], and with a medium low-income, Lahore [33].

\section{Results}

\subsection{Income Per Capita}

To assess the MSWM in Mexico City with the reference indicators, the level of national income in the period 2011-2017 was investigated, based on the statistics generated by the World Bank for the Gross National Income per capita calculated by the Atlas method, which remained at a medium-high level [40]. 


\subsection{Waste Generation and Composition}

The generation of waste corresponds to the context indicators W.1 (generation per capita per year) and W.2 (composition of waste). Indicator W.1 is considered positive if there is a decrease in the MSW, since this represents an advance in prevention, which is the option with the highest position in the hierarchy for the comprehensive MSWM. For indicator W.2 it is expected that there should be an increase in the percentage of organic waste since a greater part of the inorganic waste is being reduced or reused. Mexico City is the city that generates most waste and with the highest generation rate per capita in Mexico according to the National Census of Municipal and Boroughs Governments 2017 [41].

Figure 2 shows the growth of the generation of MSW in Mexico City, with data collected by the General Directorate of Urban Services (GDUS) in the Solid Waste inventories. It is observed that the amount of MSW in Mexico has increased by 3.29\% in the analyzed period, with no improvement in the reduction and reuse strategies, the results of the most recent study on the composition of the MSW dating from 2008, which was carried out at the transfer stations. It should be noted that $77.13 \%$ of the MSW can be exploited, since $27.18 \%$ is susceptible to recovery, $49.95 \%$ is organic, and only $22.97 \%$ is other types of waste that are not suitable for organic recovery or treatment. Another relevant fact is that if these data are compared with the composition of the MSW at the national level, there is a difference of $11.49 \%$ between the percentage of reusable MSW, which is attributed to the recovery of waste carried out by the collection workers and those who are creating it [42].

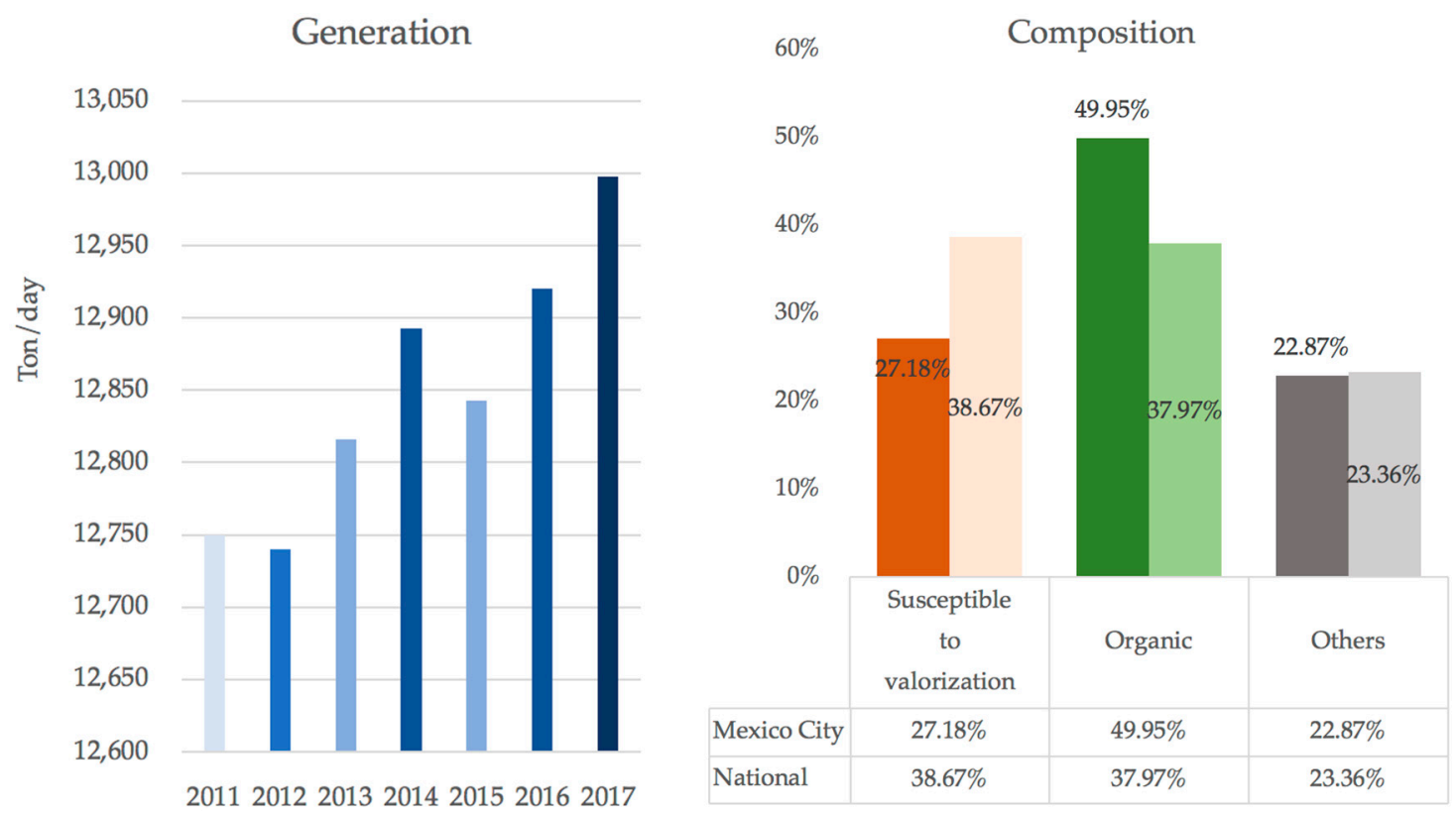

Figure 2. Generation and Composition of Municipal Solid Waste (MSW) in Mexico City and at the national level [42-45].

\subsection{Physical Component}

Figure 3 shows all the physical components, the relationships between them, and the stakeholder group to which each belongs. In Mexico City, local legislation indicates that the inhabitants have to divide MSW into two fractions: organic and inorganic. The squares in dotted lines in Figure 3 indicate the activities carried out by the inhabitants. Since the separation of all MSWs has not yet achieved, a part of them is collected mixed, for which shown on the figure that there are two different types of storage, mixed and buried. 


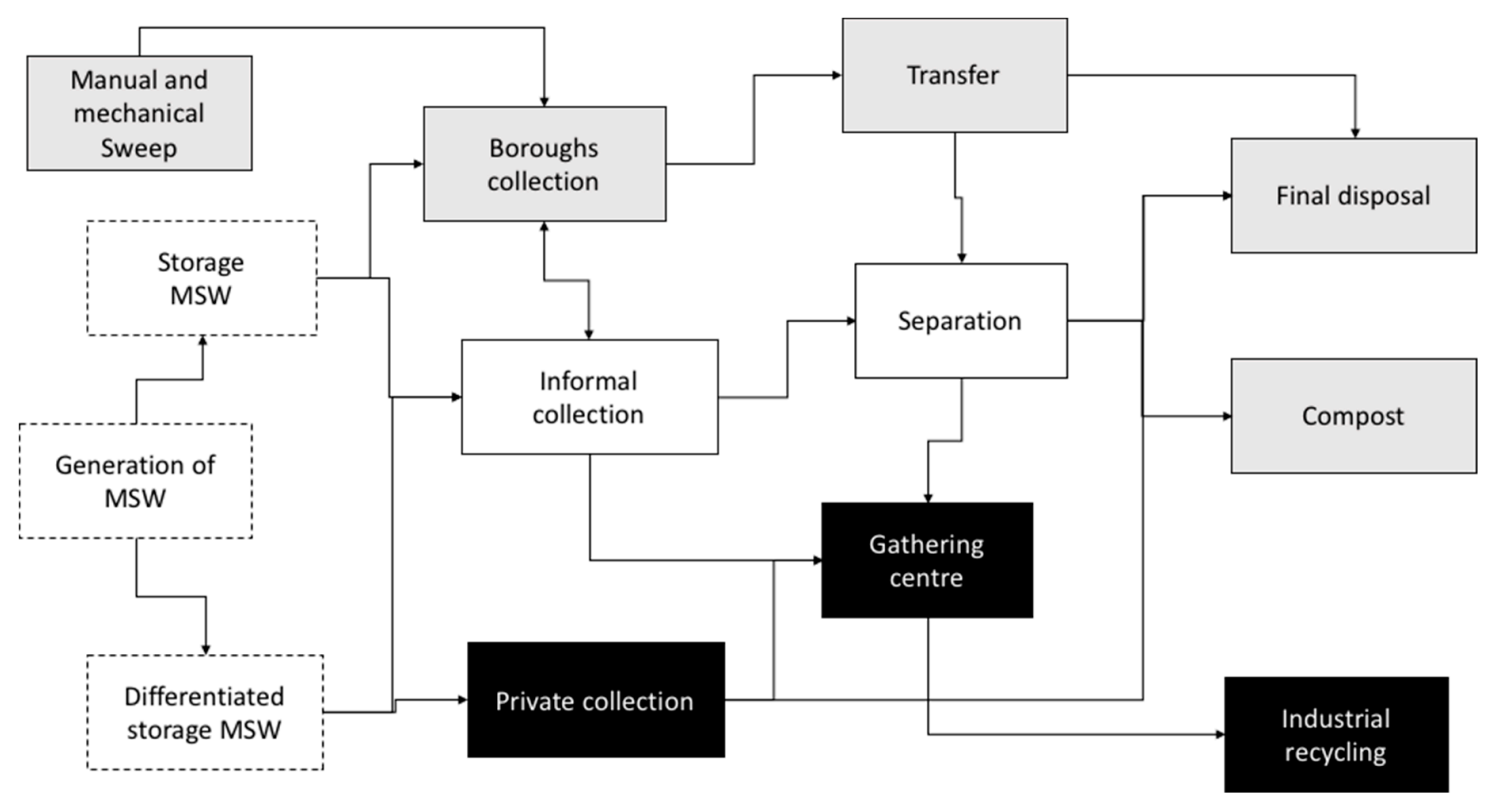

Figure 3. Municipal Solid Waste Management (MSWM) in Mexico City.

The services that are provided by public services are indicated in grey rectangles. Public services perform the collection of separate MSWs, which are then deposited in the transfer stations and from there are sent for treatment or final disposal. In the case of inorganic solid waste, one part is sent to separation plants to recover anything with economic value for recycling, and the rest is sent to the final disposal sites in neighboring states. Meanwhile, the organic part is sent to the western compost plant and the remaining inorganic waste is sent for final disposal [14].

Black rectangles refer to private services. Private collection collects the MSW in conditions that the users find more convenient, mainly in commercial and service establishments. If they are classified, they are delivered to the collection centers and otherwise they are sent for final disposal, depending on the destination the cost of the service established [43].

The white rectangles indicate the activities carried out by informal workers. The types of MSW that are handled by informal workers are mostly those that have an economic value, and these are collected voluntarily door-to-door from homes or at the transfer stations. The MSWs with economic value are classified by the type of material they are made from and conditioned for sale to the collection centers for subsequent recycling, while those that have no value are delivered to the delegation collection [20].

\subsubsection{Public Health (Waste Collection)}

To assess the physical component of the collection, three indicators are used: two quantitative indicators that correspond to the collection coverage and the amount of MSW collected by the system, and a qualitative indicator used to evaluate the quality of the collection service.

The indicator 1.1 that measures the coverage of the collection is the proportion between the MSW collected and generated. Figure 4 shows the amount of MSW collected in Mexico City during the period 2011-2017, where the percentage obtained was between $72 \%$ and $82 \%$. In 2011, a maximum coverage of 82.4\% was obtained, which progressively decreased between 2011 and 2013 immediately after the closure of the Bordo Poniente landfill, until it reached a minimum of $72.5 \%$, and subsequently increased until 2017, when it returned to a coverage of $82.1 \%$. Hence, in this area no improvement was recorded, since it was established that a percentage of $70-80 \%$ corresponds to an average level, which makes it evident that there is a deficiency in this area, considering that the level of income and GDP of the country is medium-high. For this reason, a better result of at least $90 \%$ of collection coverage would be expected. This shortfall is attributed mainly to a lack of control over the providers of private and informal services, meaning that the exact amount of waste is unknown. Although there 
is a significant number of clandestine dumps, it is not a city that is perceived as dirty by the citizenship and the amount of waste that reaches the different treatments and the final disposal is in fact reportedly greater than $90 \%$ [21].

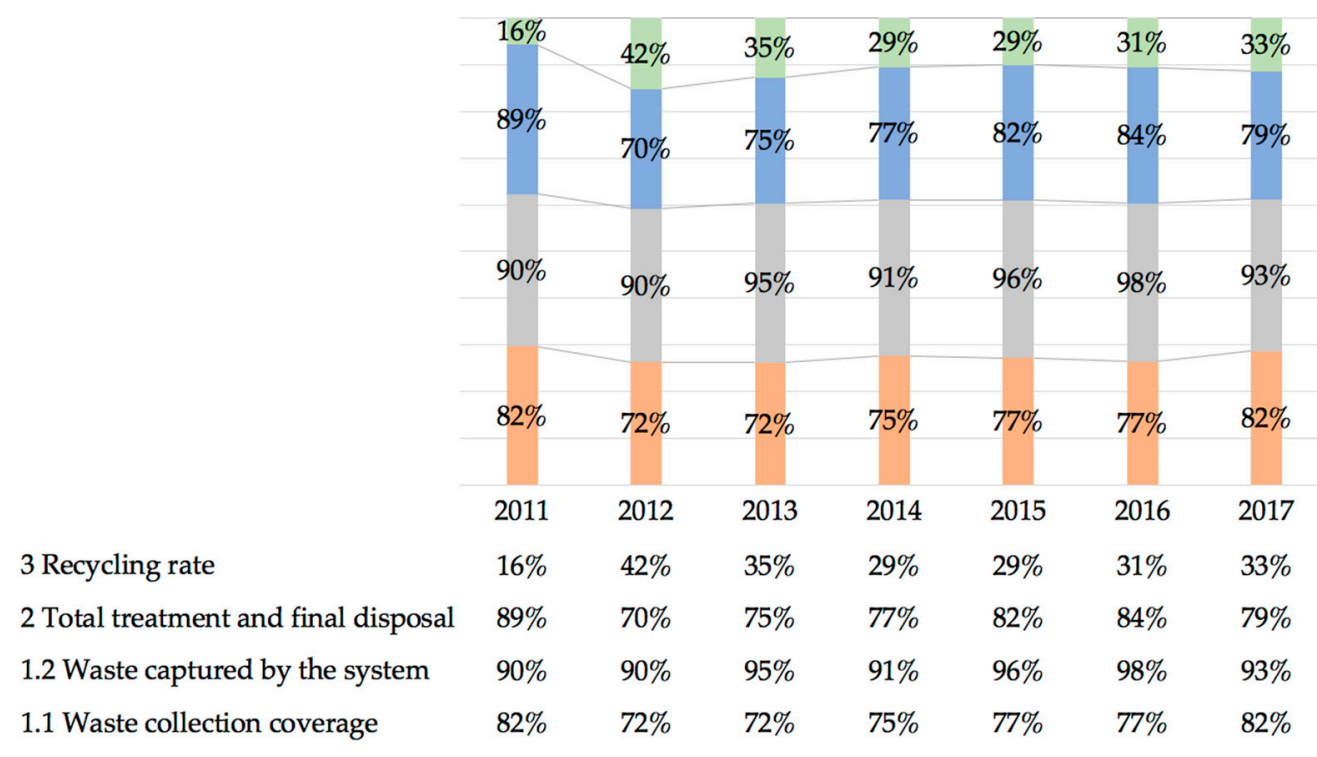

Figure 4. Quantitative Indicators [43,45].

Indicator 1.2 represents the proportion between the MSWs arriving for the different treatments and final disposal and the total that is generated, as shown in Figure 4. During the analyzed period there was no deficiency in the amount of waste collected by the system, since it remained above $90 \%$, which corresponds to a medium-high level according to the income level of the country. To reach this high level, $99 \%$ of the waste would need to be captured, which would require an increase in the collection coverage, after which most clandestine dumps would disappear.

Finally, for the quality indicator for the collection service, Table 2 shows the parameters that evaluate the quality of the collection. These focus on the appearance of the city, and the infrastructure, personnel, and planning of this service. Each of these parameters is evaluated assigning a rating of 0,5, 10,15 , or 20 corresponding to a low, medium-low, medium, medium-high, and high level. In the case of Mexico City, only one score was obtained, since new techniques or changes in the infrastructure have not been implemented that modify the quality of the service. On average, a medium-high rating was obtained, corresponding to the range of $60-80 \%$; thus, although there is no improvement, it is considered that there is no lag in relation to the economic situation of the country.

Table 2. Evaluation of the quality of collection services.

\begin{tabular}{cccc}
\hline Number & Criterion & 2011-2017 & Observations \\
\hline 1C.1 & Appearance of waste collection points & 15 & Medium \\
1C.2 & Effectiveness of street cleaning & 20 & Medium-high \\
1C.3 & Effectiveness of collection in low income districts & 10 & Medium \\
1C.4 & Efficiency and effectiveness of waste transport & 20 & Medium-high \\
1C.5 & Appropriateness of service planning and monitoring & 10 & Medium \\
1C.6 & Health and safety of collection workers & 5 & Medium-low \\
\cline { 1 - 2 } & Total score & 80 & \multirow{2}{*}{ Medium-high } \\
\cline { 1 - 2 } 1.C Quality of waste collection service * (Total score-normalized) & $66.7 \%$ & \\
\hline
\end{tabular}

* Rate of MSWs sent to final disposal and treatment among those that are generated, minus those recycled by informal workers and in the separation plants of the city. 


\subsubsection{Environmental Control (Waste Treatment and Disposal)}

The final destination of the MSW in Mexico City was the Bordo Poniente landfill located in the neighboring State of Mexico until its closure in 2011. As of that moment, the treatment of the organic fraction of the MSW began to be progressively increased, without yet occupying a predominant position, as claimed by the Local Environmental Policy.

Since the closure of Bordo Poniente Landfill in 2011, and due to the lack of suitable land, Mexico City does not have its own site; thus, agreements were signed with five different sites for final disposal, four in the State of Mexico and one in the State of Morelos, which in consideration of the service assumed responsibility for the proper final disposal of the MSW in compliance with current environmental regulations. Pollution control is measured by two indicators, one quantitative and one qualitative, where quantitative means the proportion of MSWs that are treated or sent for final disposal among the total MSW generated minus those that are recycled or reused.

The quantitative indicator 2, which refers to the proportion of MSWs that are treated or sent for final disposal among those that are generated, minus those that are recycled by informal workers, reached a medium-high level during the analyzed period, with an increase up to 2016, when it reached the maximum level because in that year the largest amount of MSW was received in Mexico City's separation plants for the recovery of by-products and the formulation of alternative fuels for cement kilns. In 2017, there was a decrease in the MSW destined for the recovery of by-products; thus, there was a setback to the medium level, as shown in Figure 4.

The qualitative indicator $2 \mathrm{E}$ consists of six different parameters, which are related to the control of the emissions produced by the transport, treatment and final disposal. The results are shown in Table 3 .

Table 3. Quality of environmental protection in the final disposal and treatment.

\begin{tabular}{|c|c|c|c|c|}
\hline Number & Criterion & 2011 & 2012 & 2013-2017 \\
\hline 2E.1 & $\begin{array}{l}\text { Degree of control in the reception of } \\
\text { MSW in the transfer stations }\end{array}$ & 10 & 10 & 15 \\
\hline 2E. 2 & $\begin{array}{l}\text { Degree of control over the treatment } \\
\text { and disposal of MSW }\end{array}$ & 15 & 15 & 15 \\
\hline 2E.3 & $\begin{array}{l}\text { Degree of monitoring and verification } \\
\text { of environmental controls }\end{array}$ & 5 & 10 & 10 \\
\hline 2E.4 & $\begin{array}{l}\text { Efficiency in the use of the MSW for } \\
\text { power generation }\end{array}$ & N/A & N/A & N/A \\
\hline 2E. 5 & $\begin{array}{l}\text { Degree of technical competence in the } \\
\text { planning, management, and operation } \\
\text { of the treatment and final disposal }\end{array}$ & 10 & 10 & 10 \\
\hline 2E.6 & Occupational health and safety & 15 & 15 & 15 \\
\hline & Total score & 55 & 60 & 65 \\
\hline \multirow{2}{*}{\multicolumn{2}{|c|}{$\begin{array}{l}\text { 2.E Quality of environmental protection in the final } \\
\text { disposal and treatment * (Total score-normalized) }\end{array}$}} & $55 \%$ & $60 \%$ & $65 \%$ \\
\hline & & Mediun & Mediun & Medium-high \\
\hline
\end{tabular}

* Weighted on 100 total points.

For these activities, Mexico City has 13 transfer stations for transport to final disposal in landfills [22]. During the analyzed period, pollution control was better, since during the years 2011 and 2012 the West Bank was closed, which, in addition to reaching the end of its useful life, had caused a risk of contamination of the soil and aquifers as it had no leachate extraction system. Also closed was the Miguel Hidalgo transfer station, of which there were complaints about the health of the population due to its poor location [46]. The disposal sites currently being used have machinery, daily cover and some method of waterproofing. However, none of these has leachate treatment and biogas capture, thus, a high-medium rating was assigned for the period 2012-2017 [14,22]. 


\subsubsection{Resource Value ('3Rs'—Reduce, Reuse, Recycle)}

In most cities in Mexico, recycling operates in the informal sector and Mexico City is no exception. The recycling of the MSW is done in the collection vehicles, in the streets, and in the residential areas, where informal workers, known as clothes-handlers buy or ask for waste with commercial value such as paper, cardboard, or polyethylene terephthalate (PET) bottles and metals, and then resell them at a higher price. A part of the collected waste is sent to separation plants. There are no data about the amounts of MSW that are recycled in the informal collection, but according to the National Institute of Ecology and Climate Change (INECC), an estimated 5\% of the MSWs that are collected are used by volunteers who work without a contract and are supported by the tips and sale of materials that are recovered, while the informal workers do not have any information about the types or amounts of MSW they recycle, although it is considered to be less than those recovered by the collection volunteers [44]. Finally, in the three separation plants (San Juan Aragón, Bordo Poniente, and Santa Catarina), the pepenadores (waste pickers) who lived in the rubbish dumps that existed in the city before the opening of the West Bank, work on separating the MSW manually. The only wastes recycled are those that have an economic interest for the people who work there, and their efficiency is very low. Figure 5 shows the low percentage of recovery at these plants, which on average during the period analyzed does not exceed $6.5 \%$ including recycling and thermal treatment. With the closure of the Bordo Poniente Separation Plant in 2011, the amount of MSW sent for Recycling decreased by $2 \%$ to $1 \%$, as the distance to the final disposal sites increased.

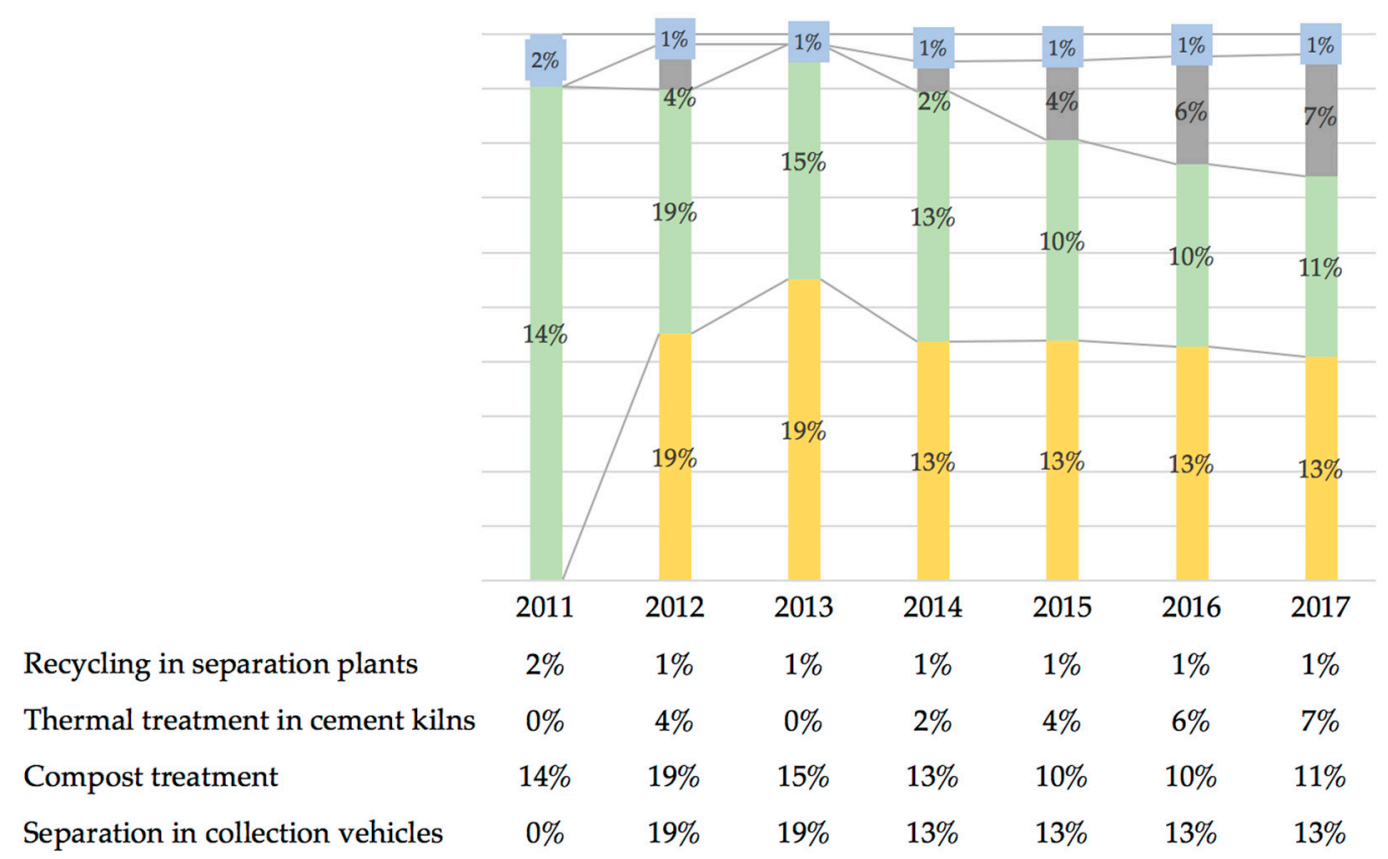

Figure 5. Recycling Rate [43,45].

As for the treatment of the MSW, Mexico City only has aerobic treatment of the rapidly biodegradable organic fraction, better known as compost. This became relevant with the closure of the West Bank, and before 2011, the amount of solid waste that was used to make compost was less than $1 \%$. Figure 5 shows that this figure increased once a compost plant with a capacity to treat up to $2000 \mathrm{t} /$ day was established in the West Bank. During 2014, it was working at $85 \%$ of its capacity and together with six more plants treated $13 \%$ of the organic waste generated in Mexico City [14].

The valorization component through recycling and reuse is evaluated with two indicators, one quantitative and the other qualitative. The quantitative indicator three measures the proportion of the MSWs that are reused or recycled in relation to the total generated. Of all the indicators that are evaluated for the physical aspects, this is the one that has the greatest lag in relation to the economic 
situation of the country, since in the analyzed period, it reached a medium value that corresponds to a range of $25-44 \%$ recovery of waste (see Figure 4); to increase this to the medium-high range, it would have to recover a percentage of $45-64 \%$. The main reason is that there is no formal organization to carry out these tasks and most of the recycling is done by the collection volunteers. According to the Secretary of the Environment of Mexico City (SEDEMA), this is an estimated 15-20\% of the wastes generated, but there are no records of this activity, while there is a record of the recovery in the transfer stations that is a minimum percentage (less than $2 \%$ of the total), since the efficiency of the plants is just $5 \%$ because the work is done manually. Finally, the treatment of the organic fraction reached just $11 \%$, whereas it could be up to $40 \%$ if the whole organic fraction were treated (Figure 5).

The 3R indicator measures the quality of the reuse and recycling actions through six different parameters, which evaluate the amount of waste that is delivered separately for its recovery, the quality of the producer of the organic treatment, the promotion by the authorities, and the participation of the citizenship in minimization actions through reuse and recycling. During the analyzed period, there was a significant increase in the separation of waste in the year immediately after the closure of the West Bank. However, since then, there has been no growth, since, although Mexico City was the first to establish a mandatory separation program, a goal has not been established to increase the percentage of recycling, neither have large-scale programs to promote the prevention and minimization of the MSW been implemented, in addition to which the plans and programs of waste management do not include the informal workers and volunteers who are recycling the largest amount of MSW. Table 4 shows, indicator 3R, was assigned a medium level for the period 2011-2017, with this parameter being below the level of income of the country.

Table 4. Quality of 3Rs provision—reduce, reuse, and recycle.

\begin{tabular}{clcc}
\hline Number & \multicolumn{1}{c}{ Criterion } & 2011 & 2012-2017 \\
\hline 3R.1 & Separation at the source of dry waste & 5 & 10 \\
\hline $3 R .2$ & Quality of recycled organic material (compost) & 20 & 20 \\
\hline $3 R .3$ & Focus on the top levels of the waste hierarchy & 15 & 15 \\
\hline $3 R .4$ & $\begin{array}{l}\text { Integration of the community and/or informal } \\
\text { recyclers with the formal SWM service }\end{array}$ & 10 & 10 \\
\hline 3R.5 & Environmental protection in recycling & 5 & 5 \\
\hline 3R.6 & Occupational health and safety & 0 & 0 \\
\hline \multicolumn{2}{c}{ Total score } & 55 & 60 \\
\cline { 2 - 4 } \begin{tabular}{l} 
3R Quality of 3Rs-reduce, reuse, recycle-provision * \\
\cline { 2 - 4 }
\end{tabular} & Medium & Medium \\
\hline
\end{tabular}

* Weighted on 120 total points.

\subsection{Governance}

The indicators related to the governance aspects are all qualitative, and each of them is integrated with seven different parameters. The governance aspect in the case of Mexico City is the one with the highest lag since all the indicators are below the medium-high level.

\subsubsection{User Inclusivity}

The $4 \mathrm{U}$ qualitative indicator contemplates equity in the provision of clean services in Mexico City, as well as the participation mechanisms and the degree of involvement of the population in the MSWM, as shown in Table 5. During the analyzed period, there were no changes in the organization of the MSWM, which was carried out in a homogeneous manner for the whole population, since the same methods were used and there was no cost. On the other hand, the implementation of separation programs, and the percentage of waste that is reused or recycled grew from 16 to $23 \%$, 
by raising awareness among the population about the environmental impacts generated by waste when it cannot be valued. As of 2014, some boroughs in Mexico City were included in a specific heading for dissemination and environmental education workshops. The participation of the population in planning the provision of solid waste management services is minimal, since there are no committees that meet regularly and no unit that deals with proposals for improvement from the population. It all comes down to having a telephone number dedicated for complaints in all the dependencies related to the handling of the MSW, and that once the Program of Prevention and Integral Management of the Residues had been elaborated, a public consultation was held. For this reason, a medium-low score was assigned in 2011 (see Table 5), and in subsequent years, only an average level was reached due to the increase in the participation of citizens in the separation work.

Table 5. Degree of user inclusivity.

\begin{tabular}{|c|c|c|c|c|c|c|c|c|}
\hline Number & Criterion & 2011 & 2012 & 2013 & 2014 & 2015 & 2016 & 2017 \\
\hline $4 \mathrm{U} .1$ & $\begin{array}{l}\text { Equity in the provision of } \\
\text { the service }\end{array}$ & 15 & 15 & 15 & 15 & 15 & 15 & 15 \\
\hline 4U.2 & Right to be heard & 10 & 10 & 10 & 10 & 10 & 10 & 10 \\
\hline \multirow{2}{*}{ 4U.3 } & \multirow{2}{*}{ User participation level } & $16 \%$ & $36 \%$ & $29 \%$ & $26 \%$ & $17 \%$ & $23 \%$ & $23 \%$ \\
\hline & & 0 & 5 & 5 & 5 & 0 & 5 & 5 \\
\hline $4 \mathrm{U} .4$ & $\begin{array}{l}\text { Feedback mechanisms } \\
\text { with users }\end{array}$ & 10 & 10 & 10 & 10 & 10 & 10 & 10 \\
\hline 4U.5 & $\begin{array}{l}\text { Awareness and user } \\
\text { education }\end{array}$ & 5 & 5 & 5 & 15 & 15 & 15 & 15 \\
\hline \multirow{2}{*}{ 4U.6 } & \multirow{2}{*}{$\begin{array}{l}\text { Effectiveness in achieving } \\
\text { behavioral changes }\end{array}$} & $16 \%$ & $47 \%$ & $62 \%$ & $39 \%$ & $29 \%$ & $43 \%$ & $43 \%$ \\
\hline & & 0 & 10 & 15 & 5 & 5 & 10 & 10 \\
\hline & Total score & 40 & 55 & 60 & 60 & 60 & 55 & 65 \\
\hline \multirow{2}{*}{\multicolumn{2}{|c|}{$\begin{array}{l}\text { 4U Degree of user inclusivity * } \\
\text { (Total score-normalized) }\end{array}$}} & $33.3 \%$ & $45.8 \%$ & $50 \%$ & $50 \%$ & $50 \%$ & $45.8 \%$ & $54.2 \%$ \\
\hline & & \multicolumn{3}{|c|}{ Medium-low } & \multicolumn{2}{|c|}{ Medium } & & \\
\hline
\end{tabular}

\subsubsection{Provider Inclusivity}

The 4P indicator evaluates the inclusion of service providers in the MSWM. During the period, there were no changes in the regulations, which do not establish a legal basis for participation and/or partnerships with private entities; thus, the contracting processes are limited to contracts with a maximum duration of one year and by means of restricted invitations. In addition to the fact that the private and informal sectors do not have any representation in the development of the plans and programs related to the MSWM, they are subject to what the local authority determines, which means that there is no adequate balance between public and private interests. In the case of private companies, they have been allowed to participate only in the final disposal, given that in the territory of Mexico City, there is no adequate space for a sanitary landfill. However, having very short hiring periods, private individuals are prevented from making long-term investments to improve the quality and environmental protection of this service. Besides that, there is a constant risk that Mexico City may run out of final disposal sites, so that only one qualification was obtained for the period analyzed, and assigned an average value (see Table 6). 
Table 6. Degree of provider inclusivity.

\begin{tabular}{ccc}
\hline Num. & Criterion & 2011-2017 \\
\hline 4 P.1 & Legal framework & 0 \\
\hline 4 P.2 & Representation of the private sector & 5 \\
\hline 4 P.3 & Role of the informal sector and citizenship & 5 \\
\hline 4 P.4 & $\begin{array}{c}\text { Balance between the interests of the private sector } \\
\text { and public provision of services }\end{array}$ & 10 \\
\hline 4 P.5 & Bidding processes & 10 \\
\hline & Total score & 30 \\
\hline & 4 I Inclusion of service providers * & $30 \%$ \\
\cline { 2 - 3 } (Total score-normalized) & Medium-low \\
\hline & $*$ Weighted on 120 total points.
\end{tabular}

\subsubsection{Financial Sustainability}

The MSWM in Mexico City is the responsibility of the city government and is free for the population, so the only source of financing is the public budget, which is exercised by the delegations in the case of manual sweeping and collection, and the GDUS for transportation, treatment, and final disposal. Table 7 shows the budget allocated to the MSWM in the period 2011-2017 in millions of Mexican pesos (MMXN), which was obtained from the annual operating program that is published each year to indicate where the public resources are being spent. In this table, it can be seen that the resources are distributed equitably between the delegations and GDUS, with 53 and 47\%, respectively. The greater part of these is destined for operations, while, by contrast, investment in new infrastructure was minimal, and for the years 2012, 2013, and 2017 it was less than $1 \%$, whereas the maximum was reached in the years 2011, 2015, and 2016, where 15\% of the budget was for investment. However, the economic resources allocated to the MSWM in the analyzed period increased above inflation. The greatest increase was registered between 2011 and 2012, when the landfill at Bordo Poniente was closed and the MSW went to private sanitary landfills (Appendix D shows the detail of the resources that were allocated to the collection and the neighborhood in each delegation and for transportation and treatment).

Table 7. Public budget for the Municipal Solid Waste Management (MSWM) [47,48].

\begin{tabular}{|c|c|c|c|c|c|c|c|}
\hline Concept & $\begin{array}{c}2011 \\
(\mathrm{MMXN})\end{array}$ & $\begin{array}{c}2012 \\
(\mathrm{MMXN})\end{array}$ & $\begin{array}{c}2013 \\
(M M X N)\end{array}$ & $\begin{array}{c}2014 \\
(\mathrm{MMXN})\end{array}$ & $\begin{array}{c}2015 \\
(M M X N)\end{array}$ & $\begin{array}{c}2016 \\
(\mathrm{MMXN})\end{array}$ & $\begin{array}{c}2017 \\
(\mathrm{MMXN})\end{array}$ \\
\hline $\begin{array}{c}\text { Borough (sweeping and } \\
\text { collection) }\end{array}$ & 1423 & 1399 & 1550 & 1940 & 1884 & 1745 & 1949 \\
\hline $\begin{array}{l}\text { GDUS (transportation, } \\
\text { treatment and final disposal) }\end{array}$ & 693 & 1006 & 1193 & 1538 & 3352 & 2547 & 1995 \\
\hline Total & 2572 & 3376 & 3608 & 3478 & 4236 & 4293 & 3944 \\
\hline Investment & 382 & 3 & 1 & 38 & 584 & 638 & 41 \\
\hline Operation & 2190 & 3373 & 3607 & 3440 & 3652 & 3655 & 3903 \\
\hline Inflation & $3.82 \%$ & $3.57 \%$ & $3.97 \%$ & $4.08 \%$ & $2.13 \%$ & $3.36 \%$ & $6.77 \%$ \\
\hline
\end{tabular}

The $5 \mathrm{~F}$ indicator is a qualitative indicator that evaluates financial sustainability as the city's capacity to improve the quality of clean-up services, the acquisition and improvement of infrastructure, without compromising public resources, according to studies carried out by the United Nation Habitat program. The UN shows that, in countries with high incomes, a greater amount of resources is available for the MSWM, but that these resources do not come from municipal revenues, but from the fees paid by users, or taxes, and the producers of packaging $[4,49,50]$. For example, in Europe, member countries have established an average tax of $\$ 30$ per ton going to a sanitary landfill [50], in order to promote treatment and recycling options. However, in Mexico City, there is no income from the 
users since the service is free, regardless of the socioeconomic level, which means that budgets are very limited, covering only the operation, and that resources for investment in new infrastructure are scarce. In the period analyzed, only in the years 2015 and 2016 were there any resources for investment in infrastructure, and Mexico City does not foresee the participation of individuals to correct these deficiencies. For this reason, only an average rating was assigned, as shown in Table 8 [47,51].

Table 8. Financial sustainability.

\begin{tabular}{ccccc}
\hline Number & Criterion & 2011-2014 & 2015-2016 & 2017 \\
\hline 5F.1 & Cost accounting & 15 & 15 & 15 \\
5F.2 & Coverage of the available budget & 10 & 15 & 10 \\
5F.3 & Local cost recovery - from households & 5 & 5 & 5 \\
5F.4 & Affordability of user charges & N/A & N/A & N/A \\
5F.5 & Pricing of disposal & 15 & 15 & 15 \\
5F.6 & Access to capital for investment & 5 & 5 & 5 \\
\hline & Total score & 50 & 55 & 50 \\
\hline & 5F Financial sustainability * & $50 \%$ & $55 \%$ & $50 \%$ \\
\cline { 2 - 5 } & (Total score-normalized) & Medium & Medium & Medium \\
\hline
\end{tabular}

* Weighted on 100 total points.

\subsubsection{Sound Institutions, Proactive Policies: National Framework}

The $6 \mathrm{~N}$ indicator measures the congruence of the legal framework on solid waste with the policies and strategies implemented by the federal government for compliance throughout the territory by local authorities and producers of goods and services.

The General Law for the Prevention and Integral Management of Solid Waste published in 2004 outlined a uniform regulation on the MSWM, defining the necessary services to handle the MSW in an appropriate form, from its generation to its final disposal and/or treatment so that, throughout, this process causes no harm to health and the environment, and, including the principles of prevention, protection and shared responsibility [52].

In order to carry out the MSWM in an appropriate way, the General Law for the Prevention and Integral Management of Waste (GLPIMW) establishes that each Municipal Government must implement a Municipal Program for the Prevention and Integral Management of Municipal Solids Waste (PMPGIMSW). This includes a basic diagnosis of the capacity and effectiveness of the available infrastructure, the policy on MSW, the definition of objectives and goals, means of financing and the mechanisms to promote the link between corresponding municipal programs, in order to create synergies. Of the 2350 municipalities in the country that have MSW and final disposal services, only 74 have a PMPGIMSW where the policies are established regarding the MSWM. These are mainly those where the main economic activity is tourism, which is why the protection and preservation of the environment is among their priorities. This makes it evident that at the municipal level, there are no well-defined public policies for the proper MSWM [41].

For the period 2012-2016, no new Program for the Prevention and Integral Management of Residues at the federal level was formulated, and the only objective established by the federal government was to promote projects for the adequate disposal of MSW that will have an intermunicipal or regional level coverage to take advantage of economies of scale [53].

On the part of the federal government, monitoring and control actions are scarce, because MSWs are the responsibility of the state governments. Each entity has different mechanisms for the implementation of the policy on waste and regulation of the treatment and disposal options. As regards the producers of goods and services, there is no arrangement with the producers of packaging and electronic devices to share the cost of handling the MSW produced after the recycling of their products. Only the bottling companies have formed a civil association for the recovery and recycling of PET [54]. However, even though $46 \%$ of the PET is recycled or sent for final disposal, the remaining $54 \%$ goes to 
unknown destinations; it could well be that it is stored for distribution and sale, or that it is disposed of clandestinely in public areas, ravines or rivers [55].

As can be seen in the Table 9 that the supervision and monitoring by the federal government of the MSWM is minimal; thus, this indicator has the lowest rating, corresponding to a medium-low level.

Table 9. Adequacy of national solid waste management framework.

\begin{tabular}{|c|c|c|c|c|}
\hline Number & Criterion & 2011 & 2012 & 2013-2017 \\
\hline $6 \mathrm{~N} .1$ & Legislation and regulations & 15 & 15 & 15 \\
\hline $6 \mathrm{~N} .2$ & Strategy and politics & 10 & 10 & 0 \\
\hline $6 \mathrm{~N} .3$ & $\begin{array}{l}\text { Guidelines for the implementation of } \\
\text { procedures }\end{array}$ & 10 & 10 & 10 \\
\hline $6 \mathrm{~N} .4$ & $\begin{array}{l}\text { National Institution that implements the } \\
\text { MSW policy }\end{array}$ & 5 & 5 & 5 \\
\hline $6 \mathrm{~N} .5$ & Regulation and control & 5 & 5 & 5 \\
\hline 6 N.6 & $\begin{array}{l}\text { Extended producer responsibility (EPR) or } \\
\text { product administration (PS) }\end{array}$ & 5 & 5 & 5 \\
\hline & Total score & 50 & 50 & 40 \\
\hline \multirow{2}{*}{\multicolumn{2}{|c|}{$\begin{array}{l}\text { 6N Adequacy of national solid waste management } \\
\text { framework* (Total score-normalized) }\end{array}$}} & $41.7 \%$ & $41.7 \%$ & $33.3 \%$ \\
\hline & & Medium-low & Medium-low & Medium-low \\
\hline
\end{tabular}

* Weighted on 120 total points.

\subsubsection{Sound Institutions, Proactive Policies: Local Institutional Policies}

Indicator $6 \mathrm{~L}$ is a measure of the institutional strength and coherence that exists between the different functions related to the MSWM, by reviewing the organizational structure, capacity and ability of inter-institutional cooperation as shown in Table 10.

Table 10. Local institutional coherence.

\begin{tabular}{|c|c|c|c|}
\hline Number & Criterion & 2011-2016 & 2017 \\
\hline 6L.1 & Organizational structure coherence & 15 & 20 \\
\hline 6L.2 & Institutional capacity & 10 & 10 \\
\hline 6L.3 & Strategic planning and MSWM in Mexico City & 15 & 15 \\
\hline 6L.4 & Availability and quality of data related to the MSWM & 15 & 15 \\
\hline 6L.5 & $\begin{array}{l}\text { Administration, control and supervision of the } \\
\text { services provided }\end{array}$ & 5 & 5 \\
\hline 6L.6 & Regional cooperation & 5 & 5 \\
\hline & Total & 65 & 70 \\
\hline \multirow{2}{*}{\multicolumn{2}{|c|}{$\begin{array}{l}\text { 6L Local institutional coherence * } \\
\text { (Total score-normalized) }\end{array}$}} & $54.1 \%$ & $58.3 \%$ \\
\hline & & Medium-high & Medium-high \\
\hline
\end{tabular}

* Weighted on 120 total points.

In 2017, Mexico City published official standards NADF-024-AMBT-2013 on the separation and recovery of Municipal Solid Waste (MSW) and on Special Management (SW), to increase the amount of collected recyclable materials and thereby decrease the quantity of landfilled material [23]. Through these instruments, it was the first entity in the country to establish the separation of MSW [56]. Nevertheless, penalties for non-compliance are only calls of attention on the part of clean workers, or restriction of the collection service if the MSW is not spread, because the City government does not monitor compliance of separation and recovery standards.

The MSWM in Mexico City is divided between the General Directorate of Urban Services (GDUS) in the operational part, the Secretariat of Works and Services for the acquisition of equipment and 
infrastructure, and the Secretariat of the Environment for the regulations and policy on waste. As of 2017, improvements were implemented to coordinate the MSWM, creating the Urban Management Agency (UMA), a decentralized body with management autonomy and with sufficient capacity to design, plan and execute the policies, programs and actions related to the MSWM. There is a single organizational chart that includes all the dependencies related to the management services of the MSW, indicating their responsibilities. However, there is no career plan with appropriate training, since most of the management positions are renewed along with the local administration every three years.

Regarding the plans and programs related to the MSWM, this is updated every 6 years, where a diagnosis of the current situation is made and strategies and actions are established for improving the MSWM. However, the amounts of money that will be available for these actions, and the financing sources, are not indicated. To follow up on the programs related to the MSWM, since 2012, an inventory of waste has been published annually, where the amount of MSWs that are managed by the public cleaning services is indicated in detail, as well as the reports of the large generators (commerce and services). However, there are unknown data on the amount of MSW and the management options used, and the most recent composition study was 9 years ago (see Figure 1). Another deficiency in the follow-up to the plans and programs is that there is no area dedicated to the supervision and monitoring of the MSW management services; only complaints, including citizen complaints, about the collection and clandestine disposal of MSW in public areas, ravines, or rivers, are dealt with.

Regarding the coordination with the neighboring entities, Mexico City comes under the Environmental Commission of the Megalopolis for the states of Hidalgo, Mexico, Moleros, Tlaxcala, and Puebla, which is an organism for political coordination on environmental issues in the states that form part of the Metropolitan Zone of the Valley of Mexico. However, this commission has in practice focused on the control of air pollution and has not addressed the MSWM in the megalopolis [57]. Derived from the above for this category, an average score was assigned for the analyzed period of 2011-2016, although there was an increase of 51.1\% to 58.3\% for the creation of the UMA. Although Mexico City has a clear organizational structure for the public service, there are no monitoring and monitoring mechanisms that can verify what is expressed in the plans and organization manuals, although it can be inferred from the results of the other indicators that not all the goals of the plans are met (see Table 10).

\section{Discussion}

\subsection{Wasteaware Indicators in Mexico City}

Using the tool of the Wasteaware benchmark indicators, it was determined that, between the physical and governance aspects, the greatest lag is in the governance aspects (see Table 11).

The physical aspects of the management of wastes in Mexico City, as in most of the megacities in developing countries, are characterized by a disposal-oriented mindset, with little regard to resource recovery and environmental protection [6]. Thus, the indicators related to the collection and final disposal of the MSW have the highest scores, reflecting an emphasis on the collection coverage and the recovery of waste. Concerning the waste collection coverage, in addition to not reaching the medium-high level, the amount of waste collected by private and informal collection services is unknown, as an analysis that only considers what is done through a formal agreement, public and/or private, does not really explain MSWM in Mexico City [20]. Previous research has highlighted the need for accurate data to assess the actual performance of all services involved in the MSWM [25].

The lowest score on the physical aspects corresponds to the resource management of both the recycling rate and the quality of the 3Rs, since these aspects do not fit into a disposal-oriented mindset. However, there is a constant growth of the recycling rate, shown by the fact that its value has doubled in the waste analyzed, growing from 16 to $32 \%$. In resource management, special importance has been given to the role of the informal sector in megacities. It has been noted that in Latin America and Asia up to $2 \%$ of the population of megacities are involved in waste management activities [58]. 
Table 11. Summary of the results of the reference indicators for the comprehensive MSWM in Mexico City.

\begin{tabular}{|c|c|c|c|c|c|c|c|c|c|}
\hline No. & Category & Indicator & \multicolumn{7}{|c|}{ Result } \\
\hline & \multicolumn{2}{|c|}{ Dates on Which the Indicator was Applied } & 2011 & 2012 & 2013 & 2014 & 2015 & 2016 & 2017 \\
\hline \multirow{2}{*}{ B.1 } & \multicolumn{2}{|c|}{ National income World Bank } & \multicolumn{7}{|c|}{ High middle income } \\
\hline & Income per capita & US $\$ /$ person & 9040 & 9750 & 9960 & 10,180 & 9840 & 9100 & 8610 \\
\hline \multirow{2}{*}{ W.1 } & \multirow{2}{*}{$\begin{array}{l}\text { Generation per capita } \\
\text { of MSW }\end{array}$} & $\mathrm{Kg} /$ year & 521 & 522 & 526 & 530 & 529 & 534 & 538 \\
\hline & & $\mathrm{Kg} /$ day & 1.428 & 1.430 & 1.441 & 1.453 & 1.450 & 1.463 & 1.475 \\
\hline W.2 & $\begin{array}{l}\text { Composition of } \\
\text { organic MSW }\end{array}$ & $\%$ & \multicolumn{7}{|c|}{$49.95 \%$} \\
\hline 1.1 & \multirow{3}{*}{$\begin{array}{l}\text { Public health- } \\
\text { waste collection }\end{array}$} & Waste collection coverage & $82 \%$ & $72 \%$ & $73 \%$ & $75 \%$ & $77 \%$ & $77 \%$ & $82 \%$ \\
\hline 1.2 & & Waste captured by the system & $90 \%$ & $90 \%$ & $95 \%$ & $95 \%$ & $96 \%$ & $98 \%$ & $93 \%$ \\
\hline $1 \mathrm{C}$ & & Quality of waste collection service & $67 \%$ & $67 \%$ & $67 \%$ & $67 \%$ & $67 \%$ & $67 \%$ & $67 \%$ \\
\hline 2 & \multirow{2}{*}{$\begin{array}{c}\text { Environmental } \\
\text { control—waste } \\
\text { treatment and disposal }\end{array}$} & Controlled treatment and disposal & $89 \%$ & $87 \%$ & $93 \%$ & $86 \%$ & $94 \%$ & $97 \%$ & $91 \%$ \\
\hline $2 \mathrm{E}$ & & $\begin{array}{l}\text { Quality of environmental protection } \\
\text { of waste treatment and disposal }\end{array}$ & $55 \%$ & $60 \%$ & $65 \%$ & $65 \%$ & $65 \%$ & $65 \%$ & $65 \%$ \\
\hline 3 & \multirow{2}{*}{$\begin{array}{l}\text { Resource value-3Rs- } \\
\text { reduce, reuse, recycle }\end{array}$} & Recycling rate & $16 \%$ & $42 \%$ & $35 \%$ & $29 \%$ & $29 \%$ & $31 \%$ & $33 \%$ \\
\hline $3 R$ & & $\begin{array}{l}\text { Quality of 3Rs-reduce, reuse, } \\
\text { recycle-provision }\end{array}$ & $46 \%$ & $55 \%$ & $50 \%$ & $50 \%$ & $50 \%$ & $55 \%$ & $50 \%$ \\
\hline $4 \mathrm{U}$ & \multirow{2}{*}{ Inclusivity } & User inclusivity & $33 \%$ & $46 \%$ & $50 \%$ & $50 \%$ & $50 \%$ & $46 \%$ & $54 \%$ \\
\hline $4 \mathrm{P}$ & & Provider inclusivity & $30 \%$ & $30 \%$ & $30 \%$ & $30 \%$ & $30 \%$ & $30 \%$ & $30 \%$ \\
\hline $5 \mathrm{~F}$ & $\begin{array}{c}\text { Financial } \\
\text { sustainability }\end{array}$ & Financial sustainability & $50 \%$ & $55 \%$ & $50 \%$ & $50 \%$ & $50 \%$ & $55 \%$ & $50 \%$ \\
\hline $6 \mathrm{~N}$ & \multirow{2}{*}{$\begin{array}{l}\text { Sound institutions, } \\
\text { proactive policies }\end{array}$} & $\begin{array}{l}\text { Adequacy of national solid waste } \\
\text { management framework }\end{array}$ & $42 \%$ & $42 \%$ & $33 \%$ & $33 \%$ & $33 \%$ & $33 \%$ & $33 \%$ \\
\hline $6 \mathrm{~L}$ & & Local institutional coherence & $54 \%$ & $54 \%$ & $54 \%$ & $54 \%$ & $54 \%$ & $54 \%$ & $58 \%$ \\
\hline
\end{tabular}


Maintaining current policies and programs could reach a medium-high level (45-64\%) in the medium term, and even though society has marginalized the valorization of MSW carried out by informal workers, this task is useful for a better environment [11]; in addition, in some cases it is done within the public collection services and helps to sustain them [12]. The main field of activity of the MSW informal sector is the recycling and recovery of materials. This activity diverts a lot of materials from final disposal and supports livelihoods for millions of poor people. There are cases in which informal recyclers divert $15-20 \%$ of the city's recyclables [59].

Within the aspects of governance, the components with the greatest lag are the inclusion of service providers and the congruence of the legal framework, both of which are at a low average level that is worrisome in the context of improving the MSWM. Current local regulations and policies do not foresee the participation of private and informal services in the MSWM, even though there is no record of the amount of MSW they handle, which affects the evaluation of indicators 1.1 and 3. It has been proposed to include the informal workers in the policies for the MSWM so as to improve their working conditions and consequently their performance; however, they cannot be successfully included in the MSW policies without a robust knowledge of how they currently operate [12], and there is a basic need in recognition of informal sector work to quantify the work they do and their importance for the MSWM [20].

A major challenge is to change the political attitudes and the public policies on the informal sector. The same is also true for the waste management industry [27]. It is becoming increasingly evident that incorporating informal recycling and collection systems into formal waste management operations and procedures can bring substantial economic, social, and environmental benefits. Strategic planning needs to document, understand and build on existing informal systems [26,28], because all the experiences demonstrate that it will be more expensive and less effective to build a new formal recycling system that ignores the one already established. Of course, this is neither an easy nor a simple task; however, it seems that there is no alternative [10].

On the other hand, the inclusion of private service providers in the service could be reflected in the $5 \mathrm{~F}$ indicator of financial sustainability, since if the private services were allowed to do a portion of the waste management, was loaded in the sectors with high-income levels. If willing and able to pay for a more efficient service, the local government could allocate more resources for investment in infrastructure to protect the environment for the benefit of the entire population. The other aspect that deserves special attention is the national legal framework. The MSWM depends on local governments, yet the federation has not developed mechanisms to verify if the national legal framework is being complied with, or if there is homogeneous management throughout the territory, and the federal government has not elaborated a corresponding national plan for solid waste.

Finally, within the aspects of governance, the component with the best performance is that of institutional strength, since Mexico City has a clear and coherent organizational structure with adequate plans and programs. The lack of monitoring and supervision diminishes its effectiveness and negatively affects the participation of the citizens, thus, an improvement in supervision would lead to an improvement in the $4 \mathrm{U}$ and $6 \mathrm{I}$ indicators.

\subsection{Wasteaware Indicator in Middle-Income Megacities}

Wasteaware Benchmark indicator also makes a possible comparison of the cities performance, including, for example, development cooperation efforts aiming at better protection of public health and the environment, increased resource recovery, and governance and comparing different policy approaches in 'similar' countries. This comparison made through a radar diagram, which shows a city performance against all 12 indicators on a zero to 100 scale. In this way, the weakness and strength of the system easily identified. In this research, to compare the performance of the city of Mexico in the MSWM were selected three megacities from a medium-income (Bangkok, Lahore, and Zhengzhou). Figure 6 shows the results of the 12 indicators of middle-income chosen cities (The score of each indicator is shown in Appendix E). 


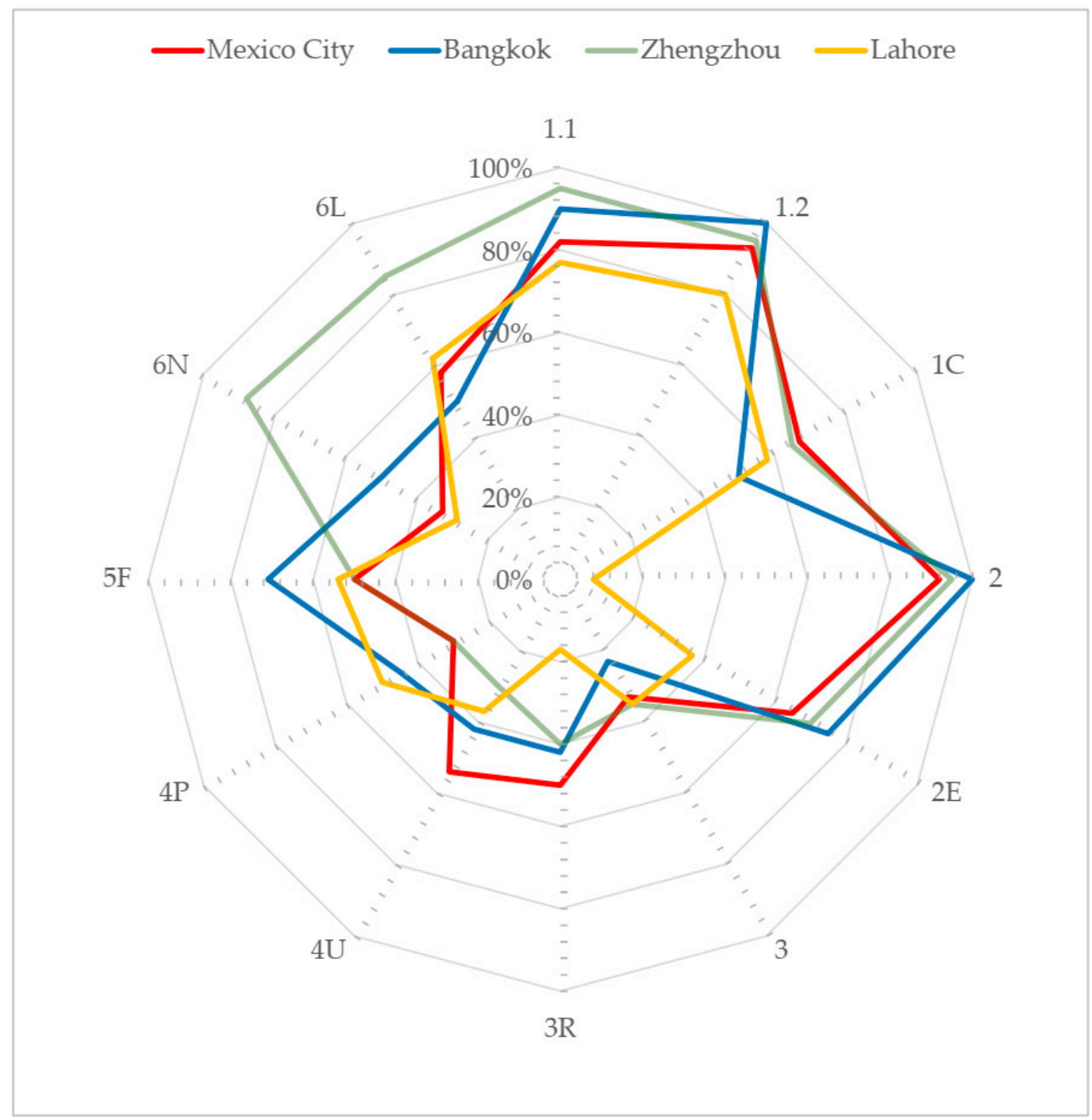

Figure 6. Comparison with cities of different levels of income.

The seven physical indicators to the right of the radar diagram, it is possible to identify that the characteristics of the selected cities are similar in the quantitative indicators with Lahore exception in 2 (Controlled treatment and disposal) and of indicator 3 (Quality of 3Rs), which are lower than the other cities analyzed. Physical aspects of the ISWM do not have significant lags identified in Mexico City in comparison to the other megacities. Governance indicators to the left of the radar diagram lag observed in all of them except $4 \mathrm{U}$.

In Provider inclusivity (4P), better performance observed in the cities of Bangkok and Lahore, in these cities, part of the collection is carried out by the private service. In the case of financial sustainability (5F), the same thing happens, Bangkok and Lahore, have a fee for household waste collection service covering a part of waste management [36,60].

Related to Adequacy of national solid waste management framework (6N), Mexico City has a lag regarding what happens in Zhengzhou, China. Chines government has strong central planning and controlling of waste management, encourages local government to develop new forms form MSW treatment. Nowadays, China has 200 Waste To Energy (WTE) plants considered the best option to recover the waste after recycling [34]. Finally, Local institutional coherence (6L), cities of Lahore and Zhengzhou, show better performance to Mexico City of Mexico, Lahore has a competent municipal enterprise to deal with the development and execution of waste management plans. The management, planning, and supervisory staff are well educated, have clear job descriptions, and trained regularly [60]. 
Concerning Zhengzhou after 2007, China has started to legitimize and facilitates the work of the informal sectors and transformed the informal sector to private sectors, his transformation only standardized the waste recycling, but also stabilized the social order [34].

\subsection{Recommendation}

Mexico City is the one that generates more waste in the country, and its generation is still growing (See Figure 2), which shows that prevention actions implemented by the city government have not had an expected effect on the population. Although it is important to note that the recycling rate in the city is more than $30 \%$ (see Figure 3), most of it recovered at the Bordo Poniente compost plant where more than $10 \%$ of the city's MSW compost [1]. $41 \%$ of the waste treated in this plant are the remains of the Central Market [21]. As the recycling of inorganic waste is mostly carried out in the collection vehicles and, in a lesser average, the stations of separation; however, this has not increased since the efficiency in the separation of MSW in the collection is 46\% [21].

To improve the aspects of waste minimization and recycling, it is necessary to increase the participation of the population in the planning of the provision of MSWM, which is minimal since there are no committees that meet regularly to make or meet new proposals to improve waste management. In the case of the private and informal sectors, they are not represented in the development of plans and programs related to the MSWM and are subject to what is determined by the local authority, which means that there is no adequate balance between public interests and private. As well as the standardization and inclusion of private and informal collection services as it has implemented in China since 2007, these services in Mexico City currently have no restrictions to receive mixed MSW, resulting in the inhabitants having alternatives for not complying with the separation of MSW.

The same applies to neighboring entities, Mexico City, depends on the Environmental Commission of the Megalopolis, which is a political coordination body on environmental issues in the states that are part of the Metropolitan Zone of the Valley of Mexico. This commission has focused on coordination and legislation on air pollution. However, it has not done in the MSWM of the metropolitan area, as in the case of sanitary landfills that operate in very different ways depending on the requirements of local and municipal governments.

A limitation to improve the infrastructure for the MSWM in Mexico City is the lack of economic resources since the City government does not receive income from the MSW, public services are free, regardless of the population's income levels. Most of the resources provided by the government go to the operation of public services. On average, investment in infrastructure was $7 \%$ in the period 2011-2017. A possible alternative would be to encourage the participation of the private sector in infrastructure investment or collection services that are the most expensive as it happens in other megacities. For which it is necessary to modify the current hiring process with private landfills and transporters, which are restricted invitations to three participants and with a maximum duration of one year. Another factor that influences the implementation of new technologies for the treatment of MSW is the lack of spaces caused by the rapid urbanization of the city, the spaces where the existing infrastructure located, or those spaces that are planned in such a way that they neighbor residential areas, caused opposition of population. In the case of transfer stations, one of the 13 city transfer stations have had to close due to protests of the neighbors to traffic it originated. Another example is that of the energy recovery incineration project promoted by the city government that rejected due to the possible increase in air pollution and affectation to the neighboring population.

Finally, the City government should improve data collection, especially about MSW composition since the last study dates from 2009, and have detailed information from the public, private and informal sectors so that the plans in Waste management is met by including all stakeholders and their characteristics. 


\section{Conclusions}

The purpose of the reference indicators is to identify the aspects that require greater emphasis to improve efficiency in the MSWM [33]. In Mexico City the greatest area of opportunity in the MSWM is in the infrastructure, as only $32 \%$ of the collector vehicles are in good condition and most of the MSW is still being sent for final disposal in sanitary landfills and not for thermal treatments, compost or anaerobic digestion, as is the case in the main cities of countries with medium-high and high income [21,49]. The main cause of this deficiency is the lack of economic resources, caused by the lack of a direct charge to users for the MSWM, which could make it possible to have properly trained personnel, equipment, and adequate infrastructure with proper maintenance [11]. This strategy could consider the possibility of establishing quotas for the higher income sectors, and thereby, subsidizing the service in marginalized areas [61].

As in all the megacities, the 'software' elements of the ISWM (institutional development, social support and participation, and financial sustainability) are becoming more and more important, especially for the success of recycling, reuse, and waste prevention initiatives. They are highly sensitive to the continuous change of the neighborhoods and cities within the megacity, especially to the poorest ones, where inadequate waste management practices create serious health and environmental risks. Clearly, the software elements control the social behavior of citizens, and thus, they are the most important for the success of recycling, reuse and waste prevention programs [62].

It can be seen in the results of the study that the greatest area of opportunity for the improvement in the MSWM is in the indicators related to the governance aspects, especially the national legal framework, where in the case of Mexico, the current legislation delegates the management of waste to states and municipalities [52], without there being a monitoring and support mechanism at the national level to verify the policies and regulations on MSW, which are instead applied discretionally in each federal entity. This situation is replicated within Mexico City; even when there are regulations and standards for the separation and use of the MSW, they are only partially fulfilled, since there is no area dedicated exclusively to the monitoring of the management system by those in charge of the service.

The key aspects in the MSWM performance in developing countries are centered on the organizational, social, and economic aspects and their context [9]. This investigation evidenced that the main deficiencies of the MSWM in Mexico City are in the aspects of governance and that, to improve their performance, a model is required that incorporates: infrastructure; the actors involved; the relationships existing between the sectors, public, private, informal and population; and their involvement and commitment in the MSWM [63,64]. This broader view of the system increases the difficulty of waste management, which requires an approach that can handle complexity [65].

Author Contributions: Study conception and design: F.G.G. and A.L.C.P.; data collection: F.G.G.; analysis and interpretation of results: F.G.G., A.L.C.P., and R.T.P.; draft manuscript preparation: F.G.G. and A.L.C.P. All authors reviewed the results and approved the final version of the manuscript.

Funding: This research received no external funding.

Conflicts of Interest: The authors declare no conflict of interest. 


\section{Appendix A}

Table A1. Physical components [33].

\begin{tabular}{|c|c|c|c|}
\hline Components & Indicator & Number & Description \\
\hline \multirow{3}{*}{ Public health waste collection } & Waste collection coverage & 1.1 & $\begin{array}{l}\text { Waste collection coverage represents the access that the population of a city has to a waste collection } \\
\text { service. }\end{array}$ \\
\hline & $\begin{array}{l}\text { Waste captured by the } \\
\text { system }\end{array}$ & 1.2 & $\begin{array}{l}\text { Waste captured by the system represents all the waste materials that are delivered to an official } \\
\text { treatment/disposal facility or to a recycling factory. }\end{array}$ \\
\hline & $\begin{array}{l}\text { Quality of waste collection } \\
\text { service }\end{array}$ & $1 C$ & $\begin{array}{l}\text { This is a composite indicator. The first step is getting waste from communities into the solid waste } \\
\text { management system, and the inter-related service of street cleaning. The next step is getting the } \\
\text { waste to final treatment or disposal facilities. The last two criteria examine, respectively, the } \\
\text { appropriateness of service planning and monitoring and the health and safety of collection workers. }\end{array}$ \\
\hline \multirow{2}{*}{$\begin{array}{l}\text { Environmental control- } \\
\text { waste treatment and disposal }\end{array}$} & $\begin{array}{l}\text { Controlled treatment and } \\
\text { disposal }\end{array}$ & 2 & $\begin{array}{l}\text { The 'numerator' in this calculation is the total waste that is dealt with in a 'controlled' facility. The } \\
\text { 'denominator' is the total solid waste destined for treatment or disposal-that is, the total waste } \\
\text { generated minus the waste recycled or reused. }\end{array}$ \\
\hline & $\begin{array}{l}\text { Degree of environmental } \\
\text { protection in waste } \\
\text { treatment and disposal }\end{array}$ & $2 \mathrm{E}$ & $\begin{array}{l}\text { This is a composite indicator made up by marking the criteria 2E.1-2E.6. Criterion 2E. } 1 \text { looks at } \\
\text { waste reception and general site management; 2E.2 at the specific waste treatment and disposal } \\
\text { processes and the operating procedures for their proper use; and 2E.3 focuses on environmental } \\
\text { controls. Criterion 2E.4 assesses the efficiency of energy generation and use. The last two criteria } \\
\text { focus on technical competence (2E.5) and on occupational health and safety (2E.6). }\end{array}$ \\
\hline \multirow{2}{*}{$\begin{array}{l}\text { Resource Management-- } \\
\text { reduce, reuse and recycle }\end{array}$} & Recycling rate & 3 & $\begin{array}{l}\text { Includes both recycling of materials and valorization/recycling of organics. Recycling in this } \\
\text { document represents a collection of public and private, formal, and informal activities that result in } \\
\text { diverting materials from disposal and recovering them in order to return them to productive use. } \\
\text { Conversion of quantitative recycling rate to 'traffic lights' colors: } \\
\text { Low red: } 0-9 \% \text {; Low/medium: red/orange: } 10-24 \% \\
\text { Medium orange: } 25-44 \% \text {; Medium/high: orange/green: } 45-64 \% \\
\text { High green: }>65 \%\end{array}$ \\
\hline & $\begin{array}{l}\text { Quality of 3Rs (Reduce, } \\
\text { Reuse and Recycle) } \\
\text { provision }\end{array}$ & $3 R$ & $\begin{array}{l}\text { This is a composite indicator made up by marking the criteria 3R.1-3R.6 below. The first two criteria } \\
\text { focus on the quality of recycling, for dry recyclables (3R.1) and for organics (3R.2). Criterion 3R.3 } \\
\text { assesses the policy and practical focus on the 'top of the hierarchy': for a higher waste generating } \\
\text { city, this means reduction and reuse, whereas for lower waste generating cities, it is primarily } \\
\text { diversion to recycling. Criterion 3R.4 recognizes the role of the 'community sector' in high-income } \\
\text { countries and of the informal recycling sector in middle- and low-income countries. The last two } \\
\text { criteria focus on environmental protection (3R.5) and health and safety (3R.6) }\end{array}$ \\
\hline
\end{tabular}


Table A2. Governance factors [33].

\begin{tabular}{|c|c|c|c|}
\hline Components & Indicator & Number & Issue \\
\hline \multirow[t]{2}{*}{ Inclusivity } & User inclusivity & $4 \mathrm{U}$ & $\begin{array}{l}\text { Represents the degree to which all users, or potential users, of solid waste services have access to services, } \\
\text { and are involved in and influence how those services are planned and implemented. } \\
\text { This is a composite indicator made up by marking the criteria } 4 \mathrm{U} .1-4 \mathrm{U} .6 \text {. Criterion } 4 \mathrm{U} .1 \text { assesses the } \\
\text { extent to which all citizens, irrespective of their income level, receive a good service. The next three } \\
\text { criteria focus on assessing the degree to which users, or potential users, of the solid waste services are } \\
\text { involved in the planning, policy formation, implementation, and evaluation of those services. The last two } \\
\text { criteria address complementary aspects of public awareness and education: } 4 \mathrm{U} .5 \text { assesses the level of } \\
\text { activity and } 4 \mathrm{U} .6 \text { its effectiveness in achieving the desired behavior change. }\end{array}$ \\
\hline & Provider inclusivity & $4 \mathrm{P}$ & $\begin{array}{l}\text { Degree of provider inclusivity represents the degree to which service providers, both municipal and } \\
\text { non-municipal (including the formal private, community or 'informal' sectors), are included in the } \\
\text { planning and implementation of solid waste and recycling services and activities. } \\
\text { This is a composite indicator made up by marking the criteria 4P.1-4P.5 below. Criterion } 4 \text { P. } 1 \text { assesses the } \\
\text { presence of legal instruments which enable both the public and private sectors to get involved in } \\
\text { providing stable waste management services. Criteria } 4 \mathrm{P} .2 \text { and } 4 \mathrm{P} .3 \text { focus in turn on representation of the } \\
\text { private sector and acknowledgement of the role of the informal/community sectors respectively. Criterion } \\
\text { 4P.4 looks at the 'balance' between public and private sector interests, so that neither party is unduly } \\
\text { advantaged over the other, while 4P.5 assesses the actual bid process. }\end{array}$ \\
\hline Financial sustainability & Financial sustainability & $5 \mathrm{~F}$ & $\begin{array}{l}\text { Represents the degree to which a city's solid waste management service is financially sustainable. } \\
\text { This is a composite indicator made up by marking the criteria 5F.1-5F.6 below. Criterion 5F. } 1 \text { assesses } \\
\text { transparent cost accounting procedures; 5F.2 the adequacy of the total budget, irrespective of the source of } \\
\text { revenues; 5F.3 local cost recovery from households; 5F.4 affordability of user charges; } 5 \mathrm{~F} .5 \text { coverage of } \\
\text { disposal costs, focusing on how far disposal is 'priced'; 5F.6 the ability to raise capital for investment }\end{array}$ \\
\hline \multirow[t]{2}{*}{$\begin{array}{l}\text { Sound institutions, } \\
\text { proactive policies }\end{array}$} & $\begin{array}{l}\text { Adequacy of national } \\
\text { SWM framework }\end{array}$ & $6 \mathrm{~N}$ & $\begin{array}{l}\text { Assesses the adequacy of the national solid waste management framework-including the degree of } \\
\text { implementation. } \\
\text { This is a composite indicator made up by marking the criteria } 6 \mathrm{~N} .1-6 \mathrm{~N} .6 \text { below. The criteria cover the } \\
\text { basic legislation and implementing regulations (6N.1); an approved and recent national strategy and clear } \\
\text { policies ( } 6 \mathrm{~N} .2) \text {; guidelines for local government on implementation (6N.3); the designation and capacity of } \\
\text { a single national responsible authority for solid waste management (6N.4); the environmental regulatory } \\
\text { agency (6N.5); and the extent to which companies responsible for the products that become solid waste } \\
\text { share the costs of its management through extended producer responsibility (6N.6) }\end{array}$ \\
\hline & $\begin{array}{l}\text { Local institutional } \\
\text { coherence }\end{array}$ & $6 \mathrm{~L}$ & $\begin{array}{l}\text { A measure of the institutional strength and coherence of the city's solid waste management functions. } \\
\text { This is a composite indicator made up by marking the criteria 6L.1-6L.6 below. The individual criteria } \\
\text { assess organizational structure, institutional capacity, city-level strategic planning, availability, and quality } \\
\text { of data, management control, and supervision of service delivery and inter-municipal co-operation. }\end{array}$ \\
\hline
\end{tabular}




\section{Appendix B}

Results of the evaluation of Quantitative indicators.

Table A3. Generation of Municipal Solid Waste [43,45].

\begin{tabular}{|c|c|c|c|c|c|c|c|c|}
\hline \multirow{2}{*}{\multicolumn{2}{|c|}{ Parameter }} & \multicolumn{7}{|c|}{ Year } \\
\hline & & 2011 & 2012 & 2013 & 2014 & 2015 & 2016 & 2017 \\
\hline Generation (Ton/da) & & 12,750 & 12,740 & 12,816 & 12,893 & 12,843 & 12,920 & 12,998 \\
\hline Population (millions of inh & ants) & 8.928 & 8.911 & 8.893 & 8.874 & 8.854 & 8.833 & 8.811 \\
\hline \multirow{2}{*}{ Generation per capita } & $\left(\frac{\mathrm{kg}}{\text { year }}\right)$ & 521.230 & 521.799 & 525.970 & 530.264 & 529.408 & 533.859 & 538.432 \\
\hline & $\left(\frac{k g}{d a y}\right)$ & 1.428 & 1.430 & 1.441 & 1.453 & 1.450 & 1.463 & 1.475 \\
\hline
\end{tabular}

Table A4. Composition of the MSW in Mexico City and at the national level [42,44].

\begin{tabular}{|c|c|c|c|c|c|}
\hline MSW Type & $\begin{array}{c}\text { Mexico } \\
\text { City } 2008\end{array}$ & $\begin{array}{c}\text { National } \\
2012\end{array}$ & Material & $\begin{array}{c}\text { Mexico } \\
\text { City } 2008\end{array}$ & $\begin{array}{c}\text { National } \\
2012\end{array}$ \\
\hline \multirow{6}{*}{$\begin{array}{l}\text { Susceptible to } \\
\text { valorization }\end{array}$} & \multirow{6}{*}{$27.18 \%$} & \multirow{6}{*}{$38.67 \%$} & Cardboard & $4.03 \%$ & $8.04 \%$ \\
\hline & & & Paper & $5.89 \%$ & $6.20 \%$ \\
\hline & & & Ferrous metals & $1.16 \%$ & $2.09 \%$ \\
\hline & & & Nonferrous metals & $0.29 \%$ & $2.88 \%$ \\
\hline & & & Plastics & $13.16 \%$ & $12.88 \%$ \\
\hline & & & Glass & $2.65 \%$ & $6.58 \%$ \\
\hline \multirow{2}{*}{ Organic } & \multirow{2}{*}{$49.95 \%$} & \multirow{2}{*}{$37.97 \%$} & Organic & $49.50 \%$ & $36.72 \%$ \\
\hline & & & Wood & $0.45 \%$ & $1.25 \%$ \\
\hline \multirow{7}{*}{ Others } & \multirow{7}{*}{$22.87 \%$} & \multirow{7}{*}{$23.36 \%$} & Sanitary waste & $10.77 \%$ & $6.52 \%$ \\
\hline & & & Textiles & $3.64 \%$ & $5.17 \%$ \\
\hline & & & Construction & $1.88 \%$ & $1.46 \%$ \\
\hline & & & Fine material & $0.80 \%$ & $3.76 \%$ \\
\hline & & & Waste management special & $1.41 \%$ & $0.00 \%$ \\
\hline & & & Hazardous waste & $0.18 \%$ & $0.00 \%$ \\
\hline & & & Others & $4.19 \%$ & $6.45 \%$ \\
\hline
\end{tabular}

Table A5. MSW collected in Mexico City [43,45].

\begin{tabular}{|c|c|c|c|c|c|c|c|}
\hline Description & $\begin{array}{c}2011 \\
\text { (Ton/Day) }\end{array}$ & $\begin{array}{c}2012 \\
\text { (Ton/Day) }\end{array}$ & $\begin{array}{c}2013 \\
\text { (Ton/Day) }\end{array}$ & $\begin{array}{c}2014 \\
\text { (Ton/Day) }\end{array}$ & $\begin{array}{c}2015 \\
\text { (Ton/Day) }\end{array}$ & $\begin{array}{c}2016 \\
\text { (Ton/Day) }\end{array}$ & $\begin{array}{c}2017 \\
\text { (Ton/Day) }\end{array}$ \\
\hline MSW generation & 12,750 & 12,740 & 12,816 & 12,893 & 12,843 & 12,920 & 12,998 \\
\hline Central supply & 927 & 585 & 585 & 585 & 585 & 585 & 585 \\
\hline Collected by delegations & 9573 & 8201 & 8230 & 8681 & 8726 & 8865 & 8967 \\
\hline Collected in main roads & 0 & 393 & 427 & 411 & 578 & 403 & 1082 \\
\hline \multirow{2}{*}{$\begin{array}{l}\text { 1.1 Waste collection coverage } \\
\text { (Total score-normalized) }\end{array}$} & 10,504 & 9220 & 9288 & 9722 & 9932 & 9891 & 10,669 \\
\hline & $82 \%$ & $72 \%$ & $72 \%$ & $75 \%$ & $77 \%$ & $77 \%$ & $82 \%$ \\
\hline
\end{tabular}


Table A6. MSW captured by the system $[43,45]$.

\begin{tabular}{cccccccc}
\hline Description & $\begin{array}{c}\mathbf{2 0 1 1} \\
\text { (Ton/Day) }\end{array}$ & $\begin{array}{c}\mathbf{2 0 1 2} \\
\text { (Ton/Day) }\end{array}$ & $\begin{array}{c}\mathbf{2 0 1 3} \\
\text { (Ton/Day) }\end{array}$ & $\begin{array}{c}\mathbf{2 0 1 4} \\
\text { (Ton/Day) }\end{array}$ & $\begin{array}{c}\mathbf{2 0 1 5} \\
\text { (Ton/Day) }\end{array}$ & $\begin{array}{c}\mathbf{2 0 1 6} \\
\text { (Ton/Day) }\end{array}$ & $\begin{array}{c}\mathbf{2 0 1 7} \\
\text { (Ton/Day) }\end{array}$ \\
\hline MSW generation & 12,750 & 12,740 & 12,816 & 12,893 & 12,843 & 12,920 & 12,998 \\
\hline Compost treatment & 1843 & 2374 & 1942 & 1690 & 1348 & 1325 & 1400 \\
\hline Final disposal (landfill) & 9465 & 6151 & 7613 & 8090 & 8677 & 8712 & 7862 \\
\hline Heat treatment (cement kilns) & 0 & 447 & 0.1 & 201 & 536 & 785 & 952 \\
\hline Recycling (separation plants) & 196 & 103 & 84 & 191 & 182 & 165 & 163 \\
\hline Total & 11,504 & 11,488 & 12,131 & 11,793 & 12,364 & 12,687 & 12,125 \\
\hline $\begin{array}{c}1.2 \text { Waste captured by the } \\
\text { system [9]. (Total } \\
\text { score-normalized) }\end{array}$ & $90 \%$ & $90 \%$ & $95 \%$ & $91 \%$ & $96 \%$ & $98 \%$ & $93 \%$ \\
\hline
\end{tabular}

Table A7. Treatment and final disposal [43,45].

\begin{tabular}{|c|c|c|c|c|c|c|c|}
\hline Site & $\begin{array}{c}2011 \\
\text { (Ton/Day) }\end{array}$ & $\begin{array}{c}2012 \\
\text { (Ton/Day) }\end{array}$ & $\begin{array}{c}2013 \\
\text { (Ton/Day) }\end{array}$ & $\begin{array}{c}2014 \\
\text { (Ton/Day) }\end{array}$ & $\begin{array}{c}2015 \\
\text { (Ton/Day) }\end{array}$ & $\begin{array}{c}2016 \\
\text { (Ton/Day) }\end{array}$ & $\begin{array}{c}2017 \\
\text { (Ton/Day) }\end{array}$ \\
\hline MSW generated & 12,750 & 12,740 & 12,816 & 12,893 & 12,843 & 12,920 & 12,998 \\
\hline Cañada & & 2866 & 2936 & 3219 & 3054 & 4332 & 2894 \\
\hline Cuautitlán & & 613 & 1677 & 1623 & 1155 & 475 & 602 \\
\hline Milagro & & 2191 & 2221 & 3010 & 4012 & 3294 & 3767 \\
\hline Xonacatlán & 9465 & 287 & 0 & 0 & 0 & 0 & 0 \\
\hline Tepozotlán & & 68 & 522 & 51 & 0 & 0 & 0 \\
\hline Cuautla & & 118 & 257 & 196 & 191 & 208 & 108 \\
\hline Other sites & & 8 & 0 & 0 & 0 & 403 & 491 \\
\hline Final disposal (landfill) & 9465 & 6151 & 7613 & 8099 & 8677 & 8712 & 7862 \\
\hline Compost treatment & 1843 & 2374 & 1942 & 1690 & 1348 & 1325 & 1400 \\
\hline Heat treatment (cement kilns) & 0 & 447 & 0.10 & 201 & 536 & 785 & 952 \\
\hline $\begin{array}{c}\text { Total treatment and final } \\
\text { disposal }\end{array}$ & 11,307 & 8972 & 9555 & 9990 & 10,561 & 10,882 & 10,214 \\
\hline $\begin{array}{l}2 \text { Treatment and final } \\
\text { disposal (Total } \\
\text { score-normalized) }\end{array}$ & $90 \%$ & $88 \%$ & $93 \%$ & $90 \%$ & $96 \%$ & $98 \%$ & $92 \%$ \\
\hline
\end{tabular}

Table A8. Recycling rate [43,45].

\begin{tabular}{|c|c|c|c|c|c|c|c|}
\hline Description & $\begin{array}{c}2011 \\
\text { (Ton/Day) }\end{array}$ & $\begin{array}{c}2012 \\
\text { (Ton/Day) }\end{array}$ & $\begin{array}{c}2013 \\
\text { (Ton/Day) }\end{array}$ & $\begin{array}{c}2014 \\
\text { (Ton/Day) }\end{array}$ & $\begin{array}{c}2015 \\
\text { (Ton/Day) }\end{array}$ & $\begin{array}{c}2016 \\
\text { (Ton/Day) }\end{array}$ & $\begin{array}{c}2017 \\
\text { (Ton/Day) }\end{array}$ \\
\hline MSW generation & 12,750 & 12,740 & 12,816 & 12,893 & 12,843 & 12,920 & 12,998 \\
\hline $\begin{array}{c}\text { Separation in collection } \\
\text { vehicles }\end{array}$ & 0 & 2413 & 2492 & 1621 & 1621 & 1700 & 1748 \\
\hline Compost treatment & 1843 & 2374 & 1942 & 1690 & 1348 & 1325 & 1400 \\
\hline $\begin{array}{l}\text { Thermal treatment in cement } \\
\text { kilns }\end{array}$ & 0 & 447 & 0 & 201 & 536 & 785 & 952 \\
\hline $\begin{array}{l}\text { Recycling in separation } \\
\text { plants }\end{array}$ & 196 & 103 & 84 & 191 & 182 & 165 & 163 \\
\hline Total recovered & 2039 & 5337 & 4518 & 3703 & 3687 & 3975 & 4263 \\
\hline 3 Recycling rate & $16 \%$ & $42 \%$ & $35 \%$ & $29 \%$ & $29 \%$ & $31 \%$ & $33 \%$ \\
\hline
\end{tabular}




\section{Appendix C}

Table A9. Results of the evaluation of qualitative indicators.

\begin{tabular}{|c|c|c|c|c|c|c|c|c|c|}
\hline \multicolumn{10}{|c|}{ 1.C Quality of Waste Collection Service } \\
\hline Number & Criterion & 2011 & 2012 & 2013 & 2014 & 2015 & 2016 & 2017 & Reason \\
\hline $1 C .1$ & $\begin{array}{l}\text { Appearance of waste } \\
\text { collection points }\end{array}$ & 15 & 15 & 15 & 15 & 15 & 15 & 15 & $\begin{array}{l}\text { For this criterion, the relationship between the existing collection } \\
\text { points and the number of clandestine landfills was taken into account, } \\
\text { considering a low incidence for a factor less than } 0.2 \text {. }\end{array}$ \\
\hline $1 C .2$ & $\begin{array}{l}\text { Effectiveness of street } \\
\text { cleaning }\end{array}$ & 20 & 20 & 20 & 20 & 20 & 20 & 20 & $\begin{array}{l}\text { There is considered to be a very low incidence of MSW present in the } \\
\text { main avenues and public spaces where there are agglomerations of } \\
\text { people, since there are manual and mechanical sweeping programs for } \\
\text { these areas. }\end{array}$ \\
\hline $1 C .3$ & $\begin{array}{l}\text { Effectiveness of collection in } \\
\text { low-income districts }\end{array}$ & 10 & 10 & 10 & 10 & 10 & 10 & 10 & $\begin{array}{l}\text { According to data from 2017, } 1229 \text { clandestine dumpsites exist, } 42 \% \text { of } \\
\text { the delegations of Iztapalapa, Cuauhtémoc and Benito Juarez. This is } \\
\text { considered a medium incidence since the delegations of Iztapalapa } \\
\text { and Cuauhtémoc concentrate the majority of marginalized areas. }\end{array}$ \\
\hline $1 C .4$ & $\begin{array}{c}\text { Efficiency and effectiveness } \\
\text { of waste transport }\end{array}$ & 20 & 20 & 20 & 20 & 20 & 20 & 20 & $\begin{array}{l}\text { This service is provided with specialized vehicles, where the container } \\
\text { boxes are owned by Mexico City and the trucks are concessioned. } \\
\text { There is greater supervision over this service if they disperse garbage } \\
\text { along the way or the trips are not paid for. }\end{array}$ \\
\hline 1C.5 & $\begin{array}{l}\text { Appropriateness of service } \\
\text { planning and monitoring }\end{array}$ & 10 & 10 & 10 & 10 & 10 & 10 & 10 & $\begin{array}{l}\text { The planning of the collection and transfer services is done according } \\
\text { to the POA (annual operating program) and this is done according to } \\
\text { the amount of MSW to be collected. In most of the dependencies this } \\
\text { amount remained constant during the period analyzed and only } \\
\text { updated the amounts every year. In terms of monitoring, there is no } \\
\text { supervision of the routes, only attention to citizens' complaints. }\end{array}$ \\
\hline $1 C .6$ & $\begin{array}{l}\text { Health and safety of } \\
\text { collection workers }\end{array}$ & 5 & 5 & 5 & 5 & 5 & 5 & 5 & $\begin{array}{l}\text { In general, the country's employees do not use personal protective } \\
\text { equipment, but in Mexico City this is more evident since most of the } \\
\text { collection employees are volunteers and are not provided with } \\
\text { uniform and/or personal protective equipment. }\end{array}$ \\
\hline & Total score & 80 & 80 & 80 & 80 & 80 & 80 & 80 & Top score 120 \\
\hline & Total score-normalized & $66.7 \%$ & $66.7 \%$ & $66.7 \%$ & $66.7 \%$ & $66.7 \%$ & $66.7 \%$ & $66.7 \%$ & \\
\hline
\end{tabular}


Table A9. Cont.

\begin{tabular}{|c|c|c|c|c|c|c|c|c|c|}
\hline \multicolumn{10}{|c|}{ 2.E Quality of Environmental Protection in the Final Disposal and Treatment } \\
\hline Number & Criterion & 2011 & 2012 & 2013 & 2014 & 2015 & 2016 & 2017 & Reason \\
\hline 2E.1 & $\begin{array}{l}\text { Degree of control in the } \\
\text { reception of MSW in the } \\
\text { transfer stations }\end{array}$ & 10 & 10 & 15 & 15 & 15 & 15 & 15 & $\begin{array}{l}\text { This is considered as a medium-high compliance, since in the transfer } \\
\text { stations, although there is no waste dispersion in their surroundings, } \\
\text { there is no control of dust and odors. For the years } 2011 \text { and } 2012 \text { it is } \\
\text { considered medium since the Miguel Hidalgo transfer station had } \\
\text { constant complaints from neighbors about the traffic congestion that it } \\
\text { originated until it closed in } 2013 \text {. }\end{array}$ \\
\hline $2 \mathrm{E} .2$ & $\begin{array}{c}\text { Degree of control over the } \\
\text { treatment and disposal of } \\
\text { MSW }\end{array}$ & 15 & 15 & 15 & 15 & 15 & 15 & 15 & $\begin{array}{l}\text { This is considered a medium-high compliance since during the } \\
\text { analyzed period, seven final disposal sites were used: Bordo Poniente, } \\
\text { and La Cañada, Milagro, Cuautitlán, Xonacatlan, Tepotzotlán, and } \\
\text { Cuautla. All have machinery, daily cover and some method of } \\
\text { waterproofing. However, none of these has leachate treatment and } \\
\text { capture of biogas. There is no better control since the closure of the } \\
\text { Bordo Poniente Landfill. }\end{array}$ \\
\hline 2E.3 & $\begin{array}{l}\text { Degree of monitoring and } \\
\text { verification of environmental } \\
\text { controls }\end{array}$ & 5 & 10 & 10 & 10 & 10 & 10 & 10 & $\begin{array}{l}\text { This is considered a medium compliance. There is no record of any } \\
\text { monitoring of ground and surface water, or treatment of leachates and } \\
\text { biogas in the final disposal sites. However, while the final disposal } \\
\text { and treatment sites have the authorizations at the local level, not all } \\
\text { final disposal sites comply with national standards. This is considered } \\
\text { to have improved since the closure of the West Bank, which did not } \\
\text { have local or national authorizations. }\end{array}$ \\
\hline $2 \mathrm{E} .4$ & $\begin{array}{l}\text { Efficiency in the use of the } \\
\text { MSW for power generation }\end{array}$ & $\mathrm{N} / \mathrm{A}$ & $\mathrm{N} / \mathrm{A}$ & $\mathrm{N} / \mathrm{A}$ & $\mathrm{N} / \mathrm{A}$ & N/A & N/A & $\mathrm{N} / \mathrm{A}$ & This is considered when there are incineration plants with energy use. \\
\hline $2 \mathrm{E} .5$ & $\begin{array}{l}\text { Degree of technical } \\
\text { competence in the planning, } \\
\text { management, and operation } \\
\text { of the treatment and final } \\
\text { disposal }\end{array}$ & 10 & 10 & 10 & 10 & 10 & 10 & 10 & $\begin{array}{l}\text { This is considered an average degree of compliance since the } \\
\text { authorities in charge of the management of the MSW change every } \\
\text { three years with the change of the local governments. In the case of } \\
\text { private operators, there is no evidence of certification of the personnel } \\
\text { requirements in the hiring process. }\end{array}$ \\
\hline 2E.6 & $\begin{array}{l}\text { Occupational health and } \\
\text { safety }\end{array}$ & 15 & 15 & 15 & 15 & 15 & 15 & 15 & $\begin{array}{l}\text { In general, the country's employees do not use personal protective } \\
\text { equipment, although in the transfer, transportation, and final disposal } \\
\text { facilities, there are voluntary and/or informal staff who are provided } \\
\text { with personal protective equipment; thus, this is assigned a high } \\
\text { average rating. }\end{array}$ \\
\hline & Total score & 55 & 60 & 65 & 65 & 65 & 65 & 65 & Top score 100 \\
\hline & Total score-normalized & $55 \%$ & $60 \%$ & $65 \%$ & $65 \%$ & $65 \%$ & $65 \%$ & $65 \%$ & \\
\hline
\end{tabular}


Table A9. Cont.

\begin{tabular}{|c|c|c|c|c|c|c|c|c|c|}
\hline \multicolumn{10}{|c|}{ 3R Quality of 3Rs-Reduce, Reuse, Recycle-Provision. } \\
\hline Number & Criterion & 2011 & 2012 & 2013 & 2014 & 2015 & 2016 & 2017 & Reason \\
\hline \multirow{2}{*}{ 3R.1 } & \multirow{2}{*}{$\begin{array}{l}\text { Separation at the source of } \\
\text { dry waste. } \\
\text { Quality of recycled organic } \\
\text { material (compost) }\end{array}$} & $14.5 \%$ & $41.4 \%$ & $38.4 \%$ & $28.8 \%$ & $26.2 \%$ & $26.3 \%$ & $27.1 \%$ & \multirow{2}{*}{$\begin{array}{l}\text { For this, the percentage of waste that the informal sector takes } \\
\text { advantage of and what is sent to make compost was considered. It } \\
\text { was evaluated for the years after the closure of Bordo Poniente with } \\
\text { an average quality. }\end{array}$} \\
\hline & & 5 & 10 & 10 & 10 & 10 & 10 & 10 & \\
\hline $3 R .2$ & $\begin{array}{c}\text { Focus on the top levels of the } \\
\text { waste hierarchy }\end{array}$ & 20 & 20 & 20 & 20 & 20 & 20 & 20 & $\begin{array}{l}\text { The material that arrives at the compost plants for treatment is the } \\
\text { material that was separated from the source, mainly coming from the } \\
\text { central supply and markets. During the manufacturing process, the } \\
\text { temperature is monitored and the material is sieved so that the final } \\
\text { product has a homogeneous quality. }\end{array}$ \\
\hline $3 R .3$ & $\begin{array}{l}\text { Integration of the community } \\
\text { and/or informal recyclers } \\
\text { with the formal SWM service }\end{array}$ & 15 & 15 & 15 & 15 & 15 & 15 & 15 & $\begin{array}{l}\text { The national level is the first to establish a compulsory separation } \\
\text { program focused on separation efforts and not on prevention and } \\
\text { minimization. In addition, no goals have been established to increase } \\
\text { the percentage of recycling, which remains at the same levels since } \\
\text { 2011. For this reason, the compliance is considered as medium. }\end{array}$ \\
\hline $3 R .4$ & $\begin{array}{l}\text { Environmental protection in } \\
\text { recycling }\end{array}$ & 10 & 10 & 10 & 10 & 10 & 10 & 10 & $\begin{array}{l}\text { The institutional efforts on the integration of the community in the } \\
\text { management of the MSW focus on recycling, through publicity } \\
\text { campaigns on the increase of the fractions into which it is necessary to } \\
\text { separate the waste at source for use mainly by the informal sector. } \\
\text { This leaves aside the inclusion within the system of the informal } \\
\text { workers and individuals, thus, there is a lack of knowledge of the final } \\
\text { destination of a significant part of the waste generated in Mexico City; } \\
\text { therefore, a medium compliance is assigned. }\end{array}$ \\
\hline 3R.5 & $\begin{array}{l}\text { Occupational health and } \\
\text { safety }\end{array}$ & 5 & 5 & 5 & 5 & 5 & 5 & 5 & $\begin{array}{l}\text { There are no controls in the recycling process, either in the separation } \\
\text { of MSWs carried out by volunteers and employees of the separation } \\
\text { plants, or in the places where they are marketed and stored, with very } \\
\text { precarious conditions, or in the transport to the industrial plants. }\end{array}$ \\
\hline $3 R .6$ & $\begin{array}{l}\text { Separation at the source of } \\
\text { dry waste }\end{array}$ & 0 & 0 & 0 & 0 & 0 & 0 & 0 & $\begin{array}{l}\text { In general, the country's employees do not use personal protective } \\
\text { equipment, but in Mexico City, this is more evident, since the } \\
\text { employees who recycle waste are volunteers and/or ex-workers who } \\
\text { do not have a uniform and/or personal protection equipment. }\end{array}$ \\
\hline & Total score & 55 & 60 & 60 & 60 & 60 & 60 & 60 & \multirow{2}{*}{ Top score 120} \\
\hline & Total score-normalized & $45.8 \%$ & $50 \%$ & $50 \%$ & $50 \%$ & $50 \%$ & $50 \%$ & $50 \%$ & \\
\hline
\end{tabular}


Table A9. Cont.

\begin{tabular}{|c|c|c|c|c|c|c|c|c|c|}
\hline \multicolumn{10}{|c|}{ 4U Degree of User Inclusivity } \\
\hline Number & Criterion & 2011 & 2012 & 2013 & 2014 & 2015 & 2016 & 2017 & Reason \\
\hline $4 \mathrm{U} .1$ & $\begin{array}{c}\text { Equity in the provision of the } \\
\text { service }\end{array}$ & 15 & 15 & 15 & 15 & 15 & 15 & 15 & $\begin{array}{l}\text { There is no differentiation in the provision of the collection service } \\
\text { depending on the level of income, since in the city the fixed and } \\
\text { corner methods with rear cargo vehicles prevail, thus, the difference is } \\
\text { in areas with narrow or hard to access streets. }\end{array}$ \\
\hline $4 \mathrm{U} .2$ & Right to be heard & 10 & 10 & 10 & 10 & 10 & 10 & 10 & $\begin{array}{l}\text { There is a right to citizen participation in the process of elaboration of } \\
\text { the Integral Management Program that is updated every } 5 \text { years, but } \\
\text { there is no public consultation on the annual operating program. } \\
\text { Therefore, this is considered an average rating. }\end{array}$ \\
\hline \multirow{2}{*}{$4 \mathrm{U} .3$} & \multirow{2}{*}{ User participation level } & $16 \%$ & $36 \%$ & $29 \%$ & $26 \%$ & $19 \%$ & $17 \%$ & $23 \%$ & \multirow{2}{*}{$\begin{array}{l}\text { To determine the level of citizen participation, the reported efficiency } \\
\text { of the organic waste separation, which represents } 49 \% \text { of the total, was } \\
\text { taken as a reference. }\end{array}$} \\
\hline & & 0 & 5 & 5 & 5 & 5 & 0 & 5 & \\
\hline 4U.4 & $\begin{array}{l}\text { Feedback mechanisms with } \\
\text { users }\end{array}$ & 10 & 10 & 10 & 10 & 10 & 10 & 10 & $\begin{array}{l}\text { There are no committees composed of different sectors of the } \\
\text { population that meet periodically to discuss the management of MSW, } \\
\text { although there are telephones and mailboxes in the different agencies } \\
\text { to deal with the complaints of citizens about deficiencies in the } \\
\text { provision of cleaning services, mainly sweeping and pickup. }\end{array}$ \\
\hline 4U.5 & $\begin{array}{l}\text { Awareness and user } \\
\text { education }\end{array}$ & 5 & 5 & 5 & 15 & 15 & 15 & 15 & $\begin{array}{l}\text { Until 2014, the communication and dissemination of the MSW } \\
\text { management programs was carried out through the operating } \\
\text { personnel of the cleaning services. In the subsequent years, there was } \\
\text { a specific heading for the users' education and dissemination } \\
\text { programs. }\end{array}$ \\
\hline \multirow{2}{*}{ 4U.6 } & \multirow{2}{*}{$\begin{array}{l}\text { Effectiveness in achieving } \\
\text { behavioral changes }\end{array}$} & $16 \%$ & $47 \%$ & $62 \%$ & $39 \%$ & $34 \%$ & $29 \%$ & $43 \%$ & \multirow{2}{*}{$\begin{array}{l}\text { For this parameter, the waste reported in the management plans of the } \\
\text { commercial and service establishments was taken into account, } \\
\text { together with the efficiency in the separation of organic waste from } \\
\text { the homes. }\end{array}$} \\
\hline & & 0 & 10 & 15 & 5 & 5 & 5 & 10 & \\
\hline & Total score & 40 & 55 & 60 & 60 & 60 & 55 & 65 & \multirow{2}{*}{ Top score 120} \\
\hline & Total score-normalized & $33.3 \%$ & $45.8 \%$ & $50 \%$ & $50 \%$ & $50 \%$ & $45.8 \%$ & $54.2 \%$ & \\
\hline
\end{tabular}


Table A9. Cont.

\begin{tabular}{|c|c|c|c|c|c|c|c|c|c|}
\hline \multicolumn{10}{|c|}{ 4P Degree of Provider Inclusivity } \\
\hline Number & Criterion & 2011 & 2012 & 2013 & 2014 & 2015 & 2016 & 2017 & Reason \\
\hline $4 \mathrm{P} .1$ & Legal framework & 0 & 0 & 0 & 0 & 0 & 0 & 0 & $\begin{array}{l}\text { There is a national legal framework on waste, which indicates the } \\
\text { responsibilities and powers of the different levels of government and } \\
\text { outlines the policy on waste at the national level. In the case of MSW, } \\
\text { these attributions correspond to the government of Mexico City, } \\
\text { which has published its own law and regulation regarding MSW, as } \\
\text { well as regulations that establish the separation and treatment of some } \\
\text { fractions of MSW. However, it does not establish the bases for } \\
\text { public-private participation (PPP), private participation (PSP), or the } \\
\text { participation of the informal sector. In the 2014-2020 management } \\
\text { program, private and informal participation in recycling and } \\
\text { stockpiling is expected up to } 2020 \text {. }\end{array}$ \\
\hline $4 \mathrm{P} .2$ & $\begin{array}{l}\text { Representation of the private } \\
\text { sector }\end{array}$ & 5 & 5 & 5 & 5 & 5 & 5 & 5 & $\begin{array}{l}\text { The private and informal service providers have the possibility to } \\
\text { participate in the consultation of the Waste Management Program in } \\
\text { the same way as the population, but not in the elaboration of the plan } \\
\text { or the annual operating programs. }\end{array}$ \\
\hline $4 \mathrm{P} .3$ & $\begin{array}{l}\text { Role of the informal sector } \\
\text { and citizenship }\end{array}$ & 5 & 5 & 5 & 5 & 5 & 5 & 5 & $\begin{array}{l}\text { There is no recognition at the same level as public services, for the } \\
\text { private sector and the informal sector. Both the regulations and the } \\
\text { plans and programs do not mention the services they provide or the } \\
\text { amount of waste they handle. In the case of private companies, there } \\
\text { is only a record of the providers of transport and final disposal } \\
\text { services, but not of the methods used or the amount of MSW. }\end{array}$ \\
\hline $4 \mathrm{P} .4$ & $\begin{array}{l}\text { Balance between the interests } \\
\text { of the private sector and } \\
\text { public provision of services }\end{array}$ & 10 & 10 & 10 & 10 & 10 & 10 & 10 & $\begin{array}{l}\text { There is no adequate balance in the provision of services in Mexico } \\
\text { City. The home collection service and the sweeping is only public, } \\
\text { which does not allow the possibility of a differentiated service, or to } \\
\text { have different methods and charges depending on the level of income } \\
\text { of the population. In contrast, the final provision is exclusively by } \\
\text { individuals with whom annual contracts are made, which does not } \\
\text { allow for a long-term certainty in the quality and environmental } \\
\text { protection of this service. The participation of the private sector is } \\
\text { limited to the sweeping and collection from public areas with tourist } \\
\text { and commercial attractions such as the Reforma avenue and the center. }\end{array}$ \\
\hline
\end{tabular}


Table A9. Cont.

\begin{tabular}{|c|c|c|c|c|c|c|c|c|c|}
\hline \multicolumn{10}{|c|}{ 4P Degree of Provider Inclusivity } \\
\hline Number & Criterion & 2011 & 2012 & 2013 & 2014 & 2015 & 2016 & 2017 & Reason \\
\hline $4 \mathrm{P} .5$ & Bidding processes & 10 & 10 & 10 & 10 & 10 & 10 & 10 & $\begin{array}{l}\text { The hiring processes are not open, but limited to the invitation of three } \\
\text { suppliers since its duration is one year. However, the hiring processes } \\
\text { are transparent. Contracts can be consulted through a City website } \\
\text { and the cost and conditions of the services are known. }\end{array}$ \\
\hline & Total score & 30 & 30 & 30 & 30 & 30 & 30 & 30 & \multirow{2}{*}{ Top score 100} \\
\hline & Total score-normalized & $30 \%$ & $30 \%$ & $30 \%$ & $30 \%$ & $30 \%$ & $30 \%$ & $30 \%$ & \\
\hline \multicolumn{10}{|c|}{ 5F Financial Sustainability } \\
\hline Number & Criterion & 2011 & 2012 & 2013 & 2014 & 2015 & 2016 & 2017 & Reason \\
\hline $5 \mathrm{~F} .1$ & Cost accounting & 15 & 15 & 15 & 15 & 15 & 15 & 15 & $\begin{array}{l}\text { A high average rating is considered since the total cost of the MSW } \\
\text { management service is known, but not that of the different services } \\
\text { that comprise it. }\end{array}$ \\
\hline $5 \mathrm{~F} .2$ & $\begin{array}{c}\text { Coverage of the available } \\
\text { budget }\end{array}$ & 15 & 10 & 10 & 10 & 15 & 15 & 10 & $\begin{array}{l}\text { This is considered medium level, since the budget covers all the costs } \\
\text { of operation and maintenance, but the percentage of investment is } 1 \% \\
\text { for 2012, 2013, and 2017. Meanwhile, it is considered medium-high in } \\
\text { the years 2011, 2015, and } 2016 \text { where } 15 \% \text { of the budget is considered } \\
\text { for investment. }\end{array}$ \\
\hline $5 \mathrm{~F} .3$ & $\begin{array}{c}\text { Local cost recovery-from } \\
\text { households }\end{array}$ & 5 & 5 & 5 & 5 & 5 & 5 & 5 & $\begin{array}{l}\text { This is considered a medium-low level, since only large and high } \\
\text { volume generators that are less than } 20 \% \text { of the total users pay for a } \\
\text { particular service. }\end{array}$ \\
\hline $5 \mathrm{~F} .4$ & Affordability of user charges & N/A & N/A & N/A & N/A & N/A & N/A & N/A & This is not considered as there is no direct charge to users. \\
\hline $5 \mathrm{~F} .5$ & Pricing of disposal & 15 & 15 & 15 & 15 & 15 & 15 & 15 & $\begin{array}{l}\text { During the period analyzed, the disposal sites used belong to } \\
\text { individuals, who obtain an economic gain from the provision of the } \\
\text { service. This was assigned a grade of } 15 \text {, since it is not considered that } \\
\text { they have a budget for the closure since the contracting with Mexico } \\
\text { City is annual. }\end{array}$ \\
\hline
\end{tabular}


Table A9. Cont.

\begin{tabular}{|c|c|c|c|c|c|c|c|c|c|}
\hline \multicolumn{10}{|c|}{ 4P Degree of Provider Inclusivity } \\
\hline Number & Criterion & 2011 & 2012 & 2013 & 2014 & 2015 & 2016 & 2017 & Reason \\
\hline $5 \mathrm{~F} .6$ & $\begin{array}{l}\text { Access to capital for } \\
\text { investment }\end{array}$ & 5 & 5 & 5 & 5 & 5 & 5 & 5 & $\begin{array}{l}\text { This indicator was considered to be low, since the investments made } \\
\text { by Mexico City with its budget are used to replace and acquire new } \\
\text { infrastructure to maintain the same services, but it does not have the } \\
\text { capacity to incorporate new services. As for federal support, they are } \\
\text { conditioned to the concession of the services that Mexico City does } \\
\text { not contemplate as an option. }\end{array}$ \\
\hline & Total score & 55 & 50 & 50 & 55 & 55 & 55 & 50 & \multirow{2}{*}{ Top score 100} \\
\hline & Total score-normalized & $55 \%$ & $50 \%$ & $50 \%$ & $50 \%$ & $55 \%$ & $55 \%$ & $50 \%$ & \\
\hline \multicolumn{10}{|c|}{ 6N Adequacy of National Solid Waste Management Framework } \\
\hline Number & Criterion & 2011 & 2012 & 2013 & 2014 & 2015 & 2016 & 2017 & Reason \\
\hline $6 \mathrm{~N} .1$ & Legislation and regulations & 15 & 15 & 15 & 15 & 15 & 15 & 15 & $\begin{array}{l}\text { There is a national law and its respective regulations on solid waste, } \\
\text { which have been updated continuously and specify that the MSW is } \\
\text { the responsibility of local governments (state and municipal), so that } \\
\text { at the national level, the only regulation that exists is the official norm } \\
\text { in terms of final disposal. The other management options are left to } \\
\text { local governments. However, it has been } 14 \text { years since the } \\
\text { publication of this norm, which is why it is considered a high-average } \\
\text { compliance. Therefore, a high-average rating was assigned } \\
\text { throughout the period analyzed. }\end{array}$ \\
\hline $6 \mathrm{~N} .2$ & Strategy and politics & 10 & 10 & 0 & 0 & 0 & 0 & 0 & $\begin{array}{l}\text { In Mexico, the last national plan on waste covers the period 2009-2012, } \\
\text { which defines strategies and goals to improve the management of } \\
\text { municipal solid waste. However, this does not establish compliance } \\
\text { dates and necessary resources; it mentions possible sources of } \\
\text { financing, but not the mechanisms to access them. After 2012, the } \\
\text { national plan was not updated and no new strategy has been drawn } \\
\text { up to comply with the goals not yet reached. Because the } \\
\text { responsibility for MSW is with local governments, at the national level } \\
\text { there is only one program of financing to governments that wish to } \\
\text { implement new programs or improve their management options. }\end{array}$ \\
\hline
\end{tabular}


Table A9. Cont.

\begin{tabular}{|c|c|c|c|c|c|c|c|c|c|}
\hline \multicolumn{10}{|c|}{ 4P Degree of Provider Inclusivity } \\
\hline Number & Criterion & 2011 & 2012 & 2013 & 2014 & 2015 & 2016 & 2017 & Reason \\
\hline $6 \mathrm{~N} .3$ & $\begin{array}{l}\text { Guidelines for the } \\
\text { implementation of } \\
\text { procedures }\end{array}$ & 10 & 10 & 10 & 10 & 10 & 10 & 10 & $\begin{array}{l}\text { There are guidelines for the preparation of plans and programs for } \\
\text { management of MSW at local level, where the technical, } \\
\text { environmental, and economic requirements that must be considered } \\
\text { are specified. However, no mechanism has been developed to ensure } \\
\text { that the new facilities are built with an adequate balance between } \\
\text { national, regional, and local population needs, and it is common for } \\
\text { facilities to be abandoned due to the opposition of the population or } \\
\text { because they are not adequate for the amount and type of MSW in the } \\
\text { region. }\end{array}$ \\
\hline $6 \mathrm{~N} .4$ & $\begin{array}{l}\text { National institution that } \\
\text { implements the MSW policy }\end{array}$ & 5 & 5 & 5 & 5 & 5 & 5 & 5 & $\begin{array}{l}\text { For this indicator, a medium-low level is considered, since although } \\
\text { there is a clear policy at the national level, because the MSW is the } \\
\text { responsibility of the state governments, each entity has different } \\
\text { mechanisms for the implementation of the policy on waste. For the } \\
\text { urban services, entities usually intervene in the operational part and } \\
\text { the environment in the regulation, but there is no coordination } \\
\text { between the states, since within the Ministry of the Environment there } \\
\text { is no area dedicated to the management of MSW. }\end{array}$ \\
\hline 6N.5 & Regulation and control & 5 & 5 & 5 & 5 & 5 & 5 & 5 & $\begin{array}{l}\text { The regulation and control of the final disposal sites is in the charge of } \\
\text { each state's environmental areas, which are responsible for issuing the } \\
\text { authorizations and supervision of the final disposal and treatment } \\
\text { sites, and the level of supervision is very heterogeneous. It depends a } \\
\text { lot on the resources and priorities of each state, in which more than } \\
90 \% \text { of the final disposal sites do not comply with the environmental } \\
\text { regulations but remain in operation. }\end{array}$ \\
\hline 6 N.6 & $\begin{array}{l}\text { Extended producer } \\
\text { responsibility (EPR) or } \\
\text { product administration (PS) }\end{array}$ & 5 & 5 & 5 & 5 & 5 & 5 & 5 & $\begin{array}{l}\text { Within the legal framework on waste, there is no agreement with the } \\
\text { producers of packaging and electronic devices to share the cost of } \\
\text { handling the produced MSW and to enable the recycling of their } \\
\text { products. Only the bottling companies have formed a civil association } \\
\text { for the recovery and recycling of PET produced in schools, offering the } \\
\text { recycling of their products. }\end{array}$ \\
\hline & Total score & 50 & 50 & 40 & 40 & 40 & 40 & 40 & Top score 120 \\
\hline & Total score-normalized & $41.7 \%$ & $41.7 \%$ & $33.3 \%$ & $33.3 \%$ & $33.3 \%$ & $33.3 \%$ & $33.3 \%$ & \\
\hline
\end{tabular}


Table A9. Cont.

\begin{tabular}{|c|c|c|c|c|c|c|c|c|c|}
\hline \multicolumn{10}{|c|}{ 6L Local Institutional Coherence } \\
\hline Number & Criterion & 2011 & 2012 & 2013 & 2014 & 2015 & 2016 & 2017 & Reason \\
\hline 6L.1 & $\begin{array}{l}\text { Organizational structure } \\
\text { coherence }\end{array}$ & 15 & 15 & 15 & 15 & 15 & 15 & 20 & $\begin{array}{l}\text { Until 2016, the management of the MSW was divided into the General } \\
\text { Directorate of Urban Services in the operative part, the secretariat of } \\
\text { works and services for the acquisition of equipment and infrastructure, } \\
\text { and the environment for the regulation and policy in matters of waste. } \\
\text { As of 2017, the management of the MSW is funded by the Urban } \\
\text { Management Agency (UMA), a decentralized body with management } \\
\text { autonomy, and with sufficient capacity to design, plan and execute the } \\
\text { policies, programs and actions related to the management of the MSW. }\end{array}$ \\
\hline 6L.2 & Institutional capacity & 10 & 10 & 10 & 10 & 10 & 10 & 10 & $\begin{array}{l}\text { Within the dependencies related to the management of the MSW, } \\
\text { there is an organizational chart indicating their responsibilities. } \\
\text { However, there is no career plan with appropriate training, since most } \\
\text { of the management positions are renewed with the local } \\
\text { administration every three years. }\end{array}$ \\
\hline 6L.3 & $\begin{array}{l}\text { Strategic planning and } \\
\text { management of the MSW in } \\
\text { Mexico City }\end{array}$ & 15 & 15 & 15 & 15 & 15 & 15 & 15 & $\begin{array}{l}\text { Mexico City, since the General Law for the Prevention and Integral } \\
\text { Management of Waste published in 2004, has a plan that is updated } \\
\text { every } 6 \text { years, which makes a diagnosis of the current situation and } \\
\text { establishes strategies and actions for improvement in the management } \\
\text { of the MSW. However, the amounts that will be allocated to these } \\
\text { actions or sources of financing are not indicated. }\end{array}$ \\
\hline 6L.4 & $\begin{array}{l}\text { Availability and quality of } \\
\text { data related to the } \\
\text { management of the MSW }\end{array}$ & 15 & 15 & 15 & 15 & 15 & 15 & 15 & $\begin{array}{l}\text { Since 2012, an inventory of waste is published annually, where the } \\
\text { amount of MSW that is managed by the public cleaning services, as } \\
\text { well as reports from the large generators (commerce and services) are } \\
\text { detailed. However, there is no data on the amount of MSW and } \\
\text { management options used, and the most recent composition study } \\
\text { was } 9 \text { years ago. }\end{array}$ \\
\hline 6L.5 & $\begin{array}{l}\text { Administration, control and } \\
\text { supervision of the services } \\
\text { provided }\end{array}$ & 5 & 5 & 5 & 5 & 5 & 5 & 5 & $\begin{array}{l}\text { As such, there is no area dedicated to the supervision of the MSW } \\
\text { management services, only citizen complaints or complaints are } \\
\text { received, and information on clandestine disposal of MSW in public } \\
\text { areas, ravines, or rivers, but there is no exclusive dedicated area for } \\
\text { monitoring and supervision. }\end{array}$ \\
\hline
\end{tabular}


Table A9. Cont.

\begin{tabular}{|c|c|c|c|c|c|c|c|c|c|}
\hline \multicolumn{10}{|c|}{ 6L Local Institutional Coherence } \\
\hline Number & Criterion & 2011 & 2012 & 2013 & 2014 & 2015 & 2016 & 2017 & Reason \\
\hline 6L.6 & Regional cooperation & 5 & 5 & 5 & 5 & 5 & 5 & 5 & $\begin{array}{l}\text { Mexico City belongs to the Environmental Commission of the } \\
\text { Megalopolis for the states of Hidalgo, Mexico, Moleros, Tlaxcala, and } \\
\text { Puebla, which is an organization for political coordination on } \\
\text { environmental issues of the states that are part of the Metropolitan } \\
\text { Area of the Valley of Mexico. However, this commission has focused } \\
\text { on the control of air pollution and has not addressed the management } \\
\text { of MSW in the megalopolis. }\end{array}$ \\
\hline & Total score & 65 & 65 & 65 & 65 & 65 & 65 & 70 & \multirow{2}{*}{ Top score 120} \\
\hline & score-normalized & $54.1 \%$ & $54.1 \%$ & $54.1 \%$ & $54.1 \%$ & $54.1 \%$ & $54.1 \%$ & $58.3 \%$ & \\
\hline
\end{tabular}




\section{Appendix D}

Table A10. Summary of the annual operational program for the management of the MSW in the period 2011-2017.

\begin{tabular}{|c|c|c|c|c|c|c|c|c|c|c|c|c|c|c|}
\hline \multirow{2}{*}{ Concept } & \multicolumn{2}{|c|}{2011} & \multicolumn{2}{|c|}{2012} & \multicolumn{2}{|c|}{2013} & \multicolumn{2}{|c|}{2014} & \multicolumn{2}{|c|}{2015} & \multicolumn{2}{|c|}{2016} & \multicolumn{2}{|c|}{2017} \\
\hline & Ton/Year & MDP & Ton/Year & MDP & Ton/Year & MDP & Ton/Year & MDP & Ton/Year & MDP & Ton/Year & MDP & Ton/Year & MDP \\
\hline Álvaro Obregón & 420,000 & 32.08 & 240,000 & 29.71 & 240,000 & 31.993 & 440,000 & 20.04 & 440,000 & 12.605 & 440,000 & 10.200 & 350,000 & 10.000 \\
\hline Azcapotzalco & 230,000 & 146.10 & 200,000 & 146.43 & 200,000 & 156.905 & 200,000 & 193.13 & 200,000 & 217.164 & 200,000 & 182.731 & 200,000 & 179.633 \\
\hline Benito Juárez & 299,755 & 170.60 & 269,780 & 169.75 & 242,802 & 180.530 & 218,522 & 181.27 & 218,522 & 184.232 & 218,000 & 179.641 & 218,000 & 200.934 \\
\hline Coyoacán & 390,000 & 55.84 & 273,000 & 79.41 & 390,000 & 97.288 & 390,000 & 97.15 & 390,000 & 105.897 & 390,000 & 110.483 & 390,000 & 124.216 \\
\hline Cuajimalpa & 90,000 & 17.88 & 90,000 & 16.35 & 90,000 & 16.143 & 96,000 & 20.66 & 96,000 & 28.366 & 96,000 & 38.073 & 130,000 & 42.686 \\
\hline Cuauhtémoc & 800,000 & 227.07 & 800,000 & 311.88 & 800,000 & 389.154 & 800,000 & 467.51 & 800,000 & 488.746 & 800,000 & 511.125 & 800,000 & 579.209 \\
\hline Gustavo A. Madero & $1,000,000$ & 52.31 & $1,000,000$ & 43.14 & $1,000,000$ & 30.928 & $1,000,000$ & 43.15 & $1,000,000$ & 42.871 & $1,100,000$ & 35.925 & $1,100,000$ & 31.444 \\
\hline Iztacalco & 314,000 & 15.06 & 314,000 & 3.65 & 314,000 & 10.323 & 314,000 & 18.90 & 314,000 & 21.824 & 317,000 & 37.078 & 317,000 & 39.226 \\
\hline Iztapalapa & $1,300,000$ & 237.72 & $1,300,000$ & 170.64 & $1,300,000$ & 135.098 & $1,300,000$ & 143.60 & $1,300,000$ & 107.444 & $1,341,600$ & 86.566 & $1,341,600$ & 103.960 \\
\hline Magdalena Contreras & 157,147 & 32.61 & 157,747 & 18.68 & 157,747 & 30.038 & 157,747 & 40.25 & 75,513 & 44.722 & 150,806 & 43.066 & 165,886 & 43.691 \\
\hline Miguel Hidalgo & 255,500 & 181.14 & 255,500 & 170.14 & 255,500 & 179.008 & 260,610 & 253.51 & 113,063 & 271.137 & 260,610 & 226.013 & 260,610 & 264.668 \\
\hline Milpa Alta & 30,000 & 7.82 & 39,400 & 7.80 & 30,000 & 6.860 & 30,000 & 7.09 & 30,000 & 7.479 & 30,000 & 1.616 & 30,000 & 1.916 \\
\hline Tláhuac & 167,000 & 48.28 & 160,000 & 32.85 & 160,000 & 34.828 & 160,000 & 33.57 & 150,025 & 77.300 & 150,000 & 6.226 & 150,000 & 6.973 \\
\hline Tlalpan & 150,000 & 10.31 & 340,000 & 3.34 & 7 & 4.247 & 360,000 & 56.71 & 360,000 & 38.673 & 380,000 & 31.012 & 380,000 & 36.321 \\
\hline Venustiano Carranza & 555,000 & 144.95 & 530,000 & 153.03 & 474,485 & 179.098 & 474,485 & 237.75 & 474,485 & 145.906 & 474,485 & 150.168 & 511,000 & 188.470 \\
\hline Xochimilco & 200,000 & 42.99 & 231,400 & 42.19 & 231,400 & 67.320 & 231,400 & 125.81 & 232,000 & 89.886 & 232,000 & 95.567 & 232,000 & 95.567 \\
\hline $\begin{array}{c}\text { Transport } \\
\text { Compost Treatment } \\
\text { Separation }\end{array}$ & $4,500,000$ & 693.27 & $2,555,000$ & 1005.50 & $6,112,869$ & 1192.591 & $4,036,808$ & 1538.08 & $8,548,207$ & $2,351.951$ & $9,773,263$ & 2547.385 & $9,773,558$ & 1995.142 \\
\hline Final disposal & $3,556,300$ & 421.80 & $1,640,000$ & 949.41 & $1,640,000$ & 811.235 & & & & & & & & \\
\hline Specialized collection & $1,600,000$ & 33.86 & 14,650 & 22.51 & 14,650 & 54.713 & & & & & & & & \\
\hline
\end{tabular}




\section{Appendix E}

Table A11. Comparison with cities of different levels of income and similar population $[33,34,36]$.

\begin{tabular}{|c|c|c|c|c|c|c|}
\hline Country & & US & Mexico & Tahiland & China & Pakistan \\
\hline City & & New York & Mexico City & Bangkok & Zhengzhou & Lahore \\
\hline Country Income category & B1 & High & High-middle & Upper-Midel & Lower-middle & Lower-middle \\
\hline Population & B2 & $8,623,000$ & $8,811,000$ & $10,600,000$ & $9,881,000$ & $8,160,000$ \\
\hline Waste generation & B3 & $4,562,500$ & $4,744,270$ & $4,200,000$ & $2,555,000$ & $1,916,000$ \\
\hline Waste perCapita (kg/year) & \multirow{2}{*}{ W1 } & 529 & 538 & 396 & 259 & 235 \\
\hline Waste perCapita (kg/day) & & 1.45 & 1.48 & 1.09 & 0.71 & 0.64 \\
\hline Waste collection coverage & 1.1 & $100 \%$ & $82 \%$ & $90 \%$ & $50 \%$ & $77 \%$ \\
\hline $\begin{array}{l}\text { Waste captured by the } \\
\text { system }\end{array}$ & 1.2 & $100 \%$ & $93 \%$ & $100 \%$ & $95 \%$ & $80 \%$ \\
\hline $\begin{array}{l}\text { Quality of waste } \\
\text { collection service }\end{array}$ & $1 C$ & $91 \%$ & $67 \%$ & $50 \%$ & $92 \%$ & $58 \%$ \\
\hline $\begin{array}{c}\text { Controlled treatment and } \\
\text { disposal }\end{array}$ & 2 & $100 \%$ & $92 \%$ & $100 \%$ & $100 \%$ & $8 \%$ \\
\hline $\begin{array}{l}\text { Quality of environmental } \\
\text { protection of waste } \\
\text { treatment and disposal }\end{array}$ & $2 \mathrm{E}$ & $100 \%$ & $65 \%$ & $75 \%$ & $80 \%$ & $37 \%$ \\
\hline Recycling rate & 3 & $47 \%$ & $33 \%$ & $23 \%$ & $45 \%$ & $35 \%$ \\
\hline $\begin{array}{l}\text { Quality of 3Rs-reduce, } \\
\text { reuse, recycle-provision }\end{array}$ & $3 R$ & $60 \%$ & $50 \%$ & $42 \%$ & $35 \%$ & $17 \%$ \\
\hline User inclusivity & $4 \mathrm{U}$ & $95 \%$ & $54 \%$ & $42 \%$ & $50 \%$ & $37 \%$ \\
\hline Provider inclusivity & $4 \mathrm{P}$ & $50 \%$ & $30 \%$ & $45 \%$ & $10 \%$ & $50 \%$ \\
\hline Financial sustainability & $5 \mathrm{~F}$ & $100 \%$ & $50 \%$ & $71 \%$ & $95 \%$ & $54 \%$ \\
\hline $\begin{array}{l}\text { Adequacy of national } \\
\text { solid waste management } \\
\text { framework }\end{array}$ & $6 \mathrm{~N}$ & $100 \%$ & $33 \%$ & $50 \%$ & $93 \%$ & $29 \%$ \\
\hline $\begin{array}{l}\text { Local institutional } \\
\text { coherence }\end{array}$ & 61 & $95 \%$ & $58 \%$ & $50 \%$ & $90 \%$ & $62 \%$ \\
\hline
\end{tabular}

\section{References}

1. Kaza, S.; Yao, L.; Bhada-Tata, P.; Van Woerden, F. What a Waste 2.0: A Global Snapshot of Solid Waste Management to 2050; The World Bank: Washington, DC, USA, 2018.

2. Manaf, L.A.; Samah, M.A.A.; Zukki, N.I.M. Municipal solid waste management in Malaysia: Practices and challenges. Waste Manag. 2009, 29, 2902-2906. [CrossRef] [PubMed]

3. Mavropoulos, A.; Wilson, D.C.; Appelqvist, B.; Velis, C.; Cooper, J. Globalization and Waste Management Final Report; International Solid Waste Association: Vienna, Austria, 2014.

4. Wilson, D.C.; Rodic, L.; Scheinberg, A.; Velis, C.A.; Alabaster, G. Comparative analysis of solid waste management in 20 cities. Waste Manag. Res. 2012, 30, 237-254. [CrossRef] [PubMed]

5. United Nations. World Urbanization Prospects: The 2009 Revision; UN: New York, NY, USA, 2017.

6. Escalante, N.I.; Rymkiewicz, A.; Kranert, M. Understanding Waste Management in a Megacity-Experiences in Addis Ababa, Ethiopia; International Solid Waste Association: Stuttgart, Germany, 2010.

7. Mavropoulos, A. Globalization, Megacities and Waste Management; International Solid Waste Association: Athens, Greece, 2010.

8. Wilson, D.C. Development drivers for waste management. Waste Manag. Res. 2007, 25, 198-207. [CrossRef] [PubMed]

9. Marshall, R.E.; Farahbakhsh, K. Systems approaches to integrated solid waste management in developing countries. Waste Manag. 2013, 33, 988-1003. [CrossRef] 
10. Mavropoulos, A. Megacities Sustainable Development and Waste Management in the 21st Century; International Solid Waste Association: Vienna, Austria, 2014.

11. Guerrero, L.A.; Maas, G.; Hogland, W. Solid waste management challenges for cities in developing countries. Waste Manag. 2013, 33, 220-232. [CrossRef]

12. Guibrunet, L. What is "informal" in informal waste management? Insights from the case of waste collection in the Tepito neighbourhood, Mexico City. Waste Manag. 2019, 86, 13-22. [CrossRef]

13. United Nations Human Settlements Programme. Solid Waste Management in the World's Cities: Water and Sanitation in the World's Cities 2010; UN-HABITAT/Earthscan: Nairobi, Kenya, 2010; ISBN 9781849711708.

14. Secretaría del Medio Ambiente de la Ciudad de México. PGIRS 2016-2020; Secretaría del Medio Ambiente de la Ciudad de México: Mexico City, Mexico, 2016.

15. Kennedy, C.A.; Stewart, I.; Facchini, A.; Cersosimo, I.; Mele, R.; Chen, B.; Uda, M.; Kansal, A.; Chiu, A.; Kim, K.-G.; et al. Energy and material flows of megacities. Proc. Natl. Acad. Sci. USA 2015, 112, 5985-5990. [CrossRef]

16. Secretaría del Medio Ambiente de la Ciudad de México. Programa de Gestión Integral de los Residuos Sólidos para el Distrito Federal 2009-2014. Gaceta Oficial del Distrito Federal 2009, 17, 25-133.

17. Jefatura de Gobierno Acuerdo por el que Aprueba y Expide el. Programa General de Gestión Integral de los Residuos Sólidos. Gaceta Oficial del Distrito Federal 2004, 14, 7-128.

18. Jefatura de Gobierno Regalamento de la. Ley de Residuos Sóldios del Distrito Federal. Gaceta Oficial del Distrito Federal 2008, 22, 4-24.

19. Asamblea Legislativa del Distrito Federal. Ley de Residuos Sólidos del Distrito Federal. Gaceta Oficial del Distrito Federal 2003, 22, 2-20.

20. Guibrunet, L.; Sanzana Calvet, M.; Castán Broto, V. Flows, system boundaries and the politics of urban metabolism: Waste management in Mexico City and Santiago de Chile. Geoforum 2017, 85, 353-367. [CrossRef]

21. Secretaría del Medio Ambiente de la Ciudad de México. Inventario de Residuos Sólidos CDMX 2017; Secretaría del Medio Ambiente de la Ciudad de México: Mexico City, Mexico, 2018.

22. Centro Interdisciplinario de Investigaciones y Estudios Sobre Medio Ambiente y Desarrollo. Diagnóstico Actual del Flujo de Residuos Sólidos Urbanos que se Genera en el Distrito Federal; Centro Interdisciplinario de Investigaciones y Estudios Sobre Medio Ambiente y Desarrollo: Mexico City, Mexico, 2013.

23. Tsydenova, N.; Vázquez Morillas, A.; Cruz Salas, A. Sustainability assessment of waste management system for Mexico City (Mexico)—Based on analytic hierarchy process. Recycling 2018, 3, 45. [CrossRef]

24. Castillo Berthier, H. Garbage, work and society. Resour. Conserv. Recycl. 2003, 39, 193-210. [CrossRef]

25. Wismer, S.; Lopez de Alba Gomez, A. Evaluating the Mexican Federal District's integrated solid waste management programme. Waste Manag. Res. 2011, 29, 480-490. [CrossRef]

26. Wilson, D.C.; Velis, C.; Cheeseman, C. Role of informal sector recycling in waste management in developing countries. Habitat Int. 2006, 30, 797-808. [CrossRef]

27. Wilson, D.C.; Araba, A.O.; Chinwah, K.; Cheeseman, C.R. Building recycling rates through the informal sector. Waste Manag. 2009, 29, 629-635. [CrossRef] [PubMed]

28. Scheinberg, A.; Anschütz, J. Slim pickin's: Supporting waste pickers in the ecological modernization of urban waste management systems. Int. J. Technol. Manag. Sustain. Dev. 2006, 5, 257-270. [CrossRef]

29. McLaren, R.; Coleman, D.; Mayunga, S. Sustainable management of mega growth in megacities. In Proceedings of the International Federation of Surveyors, Cairo, Egypt, 16-21 April 2005; p. 16.

30. Turcott Cervantes, D.E.; López Martínez, A.; Cuartas Hernández, M.; Lobo García de Cortázar, A. Using indicators as a tool to evaluate municipal solid waste management: A critical review. Waste Manag. 2018, 80, 51-63. [CrossRef] [PubMed]

31. Greene, K.L.; Tonjes, D.J. Quantitative assessments of municipal waste management systems: Using different indicators to compare and rank programs in New York State. Waste Manag. 2014, 34, 825-836. [CrossRef]

32. Zaman, A.U. Identification of key assessment indicators of the zero waste management systems. Ecol. Indic. 2014, 36, 682-693. [CrossRef]

33. Wilson, D.C.; Rodic, L.; Cowing, M.J.; Velis, C.A.; Whiteman, A.D.; Scheinberg, A.; Vilches, R.; Masterson, D.; Stretz, J.; Oelz, B. 'Wasteaware' benchmark indicators for integrated sustainable waste management in cities. Waste Manag. 2015, 35, 329-342. [CrossRef]

34. Yang, Y. Assessment of the Wasteaware Indicator for Selected Cities in the US and China; Columbia University: New York, NY, USA, 2018. 
35. Rana, R.; Ganguly, R.; Kumar Gupta, A. Evaluation of solid waste management in satellite Towns of Mohali and Panchkula-India. J. Solid Waste Technol. Manag. 2017, 43, 280-294. [CrossRef]

36. Chanhthamixay, B.; Vassanadumrongdee, S.; Kittipongvises, S. Assessing the sustainability level of municipal solid waste management in Bangkok, Thailand by wasteaware benchmarking indicators. Appl. Environ. Res. 2017, 39, 49-61. [CrossRef]

37. Van De Klundert, A.; Anschütz, J. Integrated Sustainable Waste Management-the Concept, 1st ed.; Scheinberg, A., Ed.; WASTE: Gouda, The Netherlands, 2001; ISBN 90-76639-02-7.

38. Schübeler, P.; Wehrle, K.; Christen, J. Urban management and infrastructure. In Collaborative Programme on Municipal Solid Waste Management in Low-Income Countries; Swiss Centre for Development Cooperation in Technology and Management: St. Gallen, Switzerland, 1996.

39. Wilson, D.C.; Carpinterio Rogero, A. Background, definitions, concepts and indicators. In Global Waste Management Outlook; Cannon, T., Ed.; United Nations Environment Programme: Vienna, Austria, 2015; p. 346. ISBN 9789280734799.

40. The World Bank GDP Per Capita, Atlas Method (Current US\$). Available online: https://data.worldbank.org/ indicator/NY.GDP.PCAP.CD?end=2017\&locations=MX\&start=2011 (accessed on 31 January 2019).

41. Instituto de Estadística y Geografía Censo Nacional de Gobiernos Municipales y Delegacionales 2017. Available online: http://www.beta.inegi.org.mx/programas/cngmd/2017/ (accessed on 11 December 2018).

42. Durán, A.; Garcés, M.; Velasco, A.; Marín, J.C.; Gutiérrez, R.; Moreno, A.; Delgadillo, A. Mexico city's municipal solid waste characteristics and composition analysis. Revista Internacional de Contaminación Ambiental 2013, 29, 39-46.

43. Ayala, C.B. Análisis de la Evolución de la Gestión de los Residuos Sólidos Urbanos en el Distrito Federal 1980-2008; Instituto Politécnico Nacional: Mexico City, Mexico, 2012.

44. Instituto Nacional de Ecología y Cambio Climático. Diagnóstico Básico Para la Gestión Integral de los Residuos Versión Extensa; Instituto Nacional de Ecología y Cambio Climático: Mexico City, Mexico, 2012.

45. Secretaría del Medio Ambiente de la Ciudad de México Residuos Sólidos. Available online: https: //www.sedema.cdmx.gob.mx/programas/programa/residuos-solidos (accessed on 17 November 2018).

46. Secretaría de Energía; Banco Mundial. Evaluación Rápida del Uso de la Energía; Delegacion Miguel Hidalgo: Mexico City, Mexico, 2015.

47. Secretaría de Administración y Finanzas de la Ciudad de México Egresos. Available online: https: //data.finanzas.cdmx.gob.mx/egresos/ (accessed on 16 November 2018).

48. Banco de México Inflación, Precios, Banco de México. Available online: http://www.anterior.banxico.org.mx/ portal-inflacion/index.html (accessed on 9 January 2019).

49. Hoornweg, D.A.; Bhada, P. What a Waste: A Global Review of Solid Waste Management; World Bank: Washington, DC, USA, 2012.

50. European Environment Agency. Managing Municipal Solid Waste-a Review of Achievements in 32 European Countries-European Environment Agency; European Environment Agency: Copenhagen, Denmark, 2013.

51. Jefatura de Gobierno. Constitución Política de la Ciudad de México. Gaceta Oficial del la CDMx 2017, 20-127.

52. Secretaría de Medio Ambiente y Recursos Naturales. Ley General para la Prevención y Gestión Integral de los Residuos. D. Oficial de la Federación 2003, 10-37.

53. Secretaría de Medio Ambiente y Recursos Naturales Programa Nacional para la Prevención y Gestión Integral de Residuos 2009-2012. Available online: https://www.gob.mx/semarnat/acciones-y-programas/ programa-para-la-prevencion-y-gestion-integral-de-residuos (accessed on 11 December 2018).

54. Cámara-Creixell, J.; Scheel-Mayenberger, C. PetStar PET bottle-to-bottle recycling system, a zero-waste circular economy business model. In Towards Zero Waste; Franco-García, M.L., Carpio-Ahuilar Jorge, C., Hans, B., Eds.; Springer: Cham, Germany, 2019; pp. 191-213. ISBN 978-3-319-92931-6.

55. Muñoz-Cadena, C.E.; Arenas-Huertero, F.J.; Ramón-Gallegos, E. Comparative analysis of the street generation of inorganic urban solid waste (IUSW) in two neighborhoods of Mexico City. Waste Manag. 2009, 29, 1167-1175. [CrossRef]

56. Secretaría del Medio Ambiente del la Ciudad de México. Norma ambiental para el distrito federal NADF-024-AMBT-2013, que establece los criterios y especificaciones técnicas bajo los cuales se deberá realizar la separación, clasificación, recolección selectiva y almacenamiento de los residuos del Distrito Feder. Gaceta Oficial del Distrito Federal 2015, 18, 22-43. 
57. Comisión Ambiental de la Megalópolis ¿Qué Hacemos? Available online: https://www.gob.mx/ comisionambiental/que-hacemos (accessed on 12 December 2018).

58. Medina, M. Municipal solid waste management in third world cities: Lessons learned and a proposal for improvement. In Human Settlement Development; Sassen, S., Ed.; Eoloss Publishers: Oxford, UK, 2009; Volume III, ISBN 978-1-84826-046-7.

59. OECD. Competitive Cities in the Global Economy; OECD Territorial Reviews; OECD: Paris, France, 2006; ISBN 9789264027084 .

60. Masood, M.; Barlow, C.Y.; Wilson, D.C. An assessment of the current municipal solid waste management system in Lahore, Pakistan. Waste Manag. Res. 2014, 32, 834-847. [CrossRef]

61. Henry, R.K.; Yongsheng, Z.; Jun, D. Municipal solid waste management challenges in developing countries-Kenyan case study. Waste Manag. 2006, 26, 92-100. [CrossRef] [PubMed]

62. Mavropoulos, A.; Willson David, C.; Appelqvlst, B.; Vells, C.; Cooper, J. Globalization and waste management phase 1: Concepts and facts. Int. Solid Waste Assoc. 2012. Available online: https://www.iswa.org/index.php? eID=tx_iswaknowledgebase_download\&documentUid=2550 (accessed on 7 November 2019).

63. Ma, J.; Hipel, K.W. Exploring social dimensions of municipal solid waste management around the globe-A systematic literature review. Waste Manag. 2016, 56, 3-12. [CrossRef] [PubMed]

64. Vergara, S.E.; Tchobanoglous, G. municipal solid waste and the environment: A global perspective. Annu. Rev. Environ. Resour. 2012, 37, 277-309. [CrossRef]

65. Seadon, J.K. Sustainable waste management systems. J. Clean. Prod. 2010, 18, 1639-1651. [CrossRef]

(C) 2019 by the authors. Licensee MDPI, Basel, Switzerland. This article is an open access article distributed under the terms and conditions of the Creative Commons Attribution (CC BY) license (http://creativecommons.org/licenses/by/4.0/). 